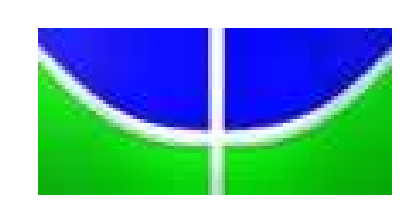

UNIVERSIDADE DE BRASÍLIA

FACULDADE DE COMUNICAÇÃO SOCIAL

PROJETO FINAL EM JORNALISMO

\title{
Operação Brasil
}

\author{
LUCIANA MACEDO MARQUES
}

ORIENTADOR: DAVID RENAULT DA SILVA

BRASÍLIA-DF

$2^{\circ}$ SEMESTRE/2008 


\section{AGRADECIMENTO}

Agradeço ao professor David Renault da Silva pela indispensável orientação para a realização desse trabalho.

Agradeço aos colegas rondonistas e aos professores Marco Antônio Mendes e Tadeu Maia pelo apoio durante as filmagens e as entrevistas.

Agradeço ao Sérgio Pasquali pela inegável contribuição pessoal e material.

Agradeço, finalmente, aos professores Marcos de Souza Mendes e David Pennington pela cooperação. 


\section{RESUMO}

Operação Brasil é um projeto experimental na forma de um documentário sobre a história e as experiências atuais do Projeto Rondon. O programa, que teve início em 1967, é um trabalho voluntário que pretende levar à juventude universitária de todo o país a conhecer realidades diferentes em diversos estados, promover a integração nacional e fortalecer a cidadania. Os jovens realizam oficinas e palestras em municípios distantes da universidade onde estudam e encontram, nos locais em que atuam, formas de vida distintas das que estão acostumados a conviver. A idéia surgiu quando fui chamada para participar do projeto como rondonista ${ }^{1}$ em julho de 2008 e me interessei na divulgação do trabalho para a sociedade. Portanto, o documentário tem a visão autoral de uma universitária que participou das atividades. Além de descrever as características do filme proposto, o trabalho apresenta inquietações que surgiram durante a realização do projeto, como a relação entre o jornalismo e o documentário, suas semelhanças e diferenças.

PALAVRAS-CHAVE: Rondon, universitário, realidade, exército, voluntariado.

\footnotetext{
${ }^{1}$ Rondonista é o universitário que participa do Projeto Rondon.
} 


\section{SUMÁRIO}

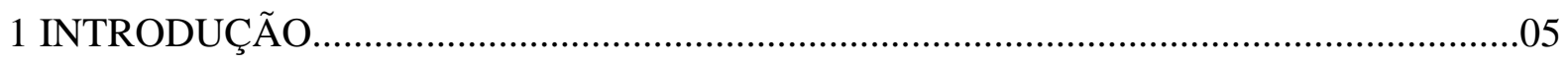

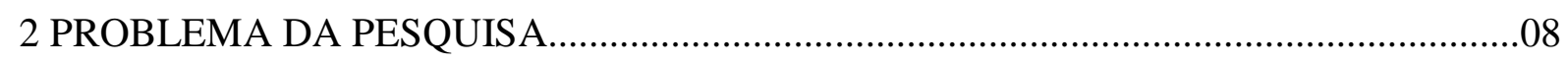

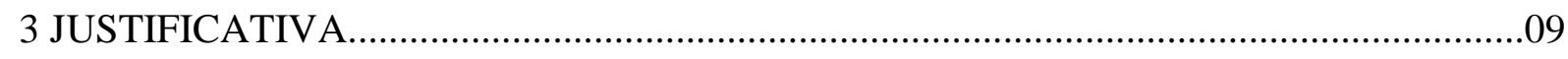

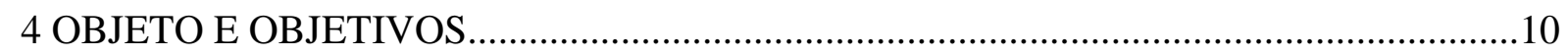

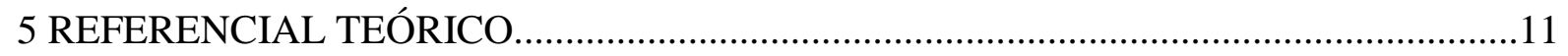

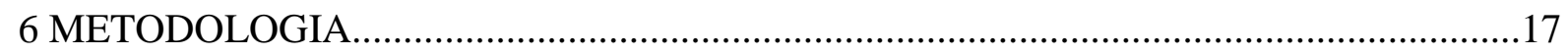

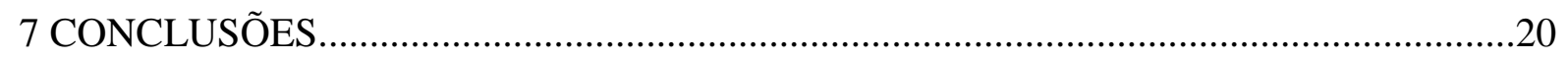

BIBLIOGRAFIA

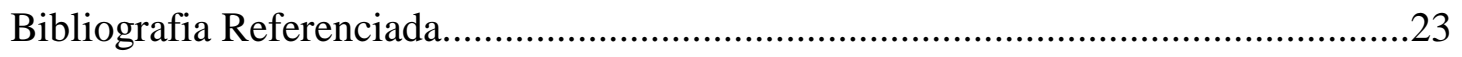

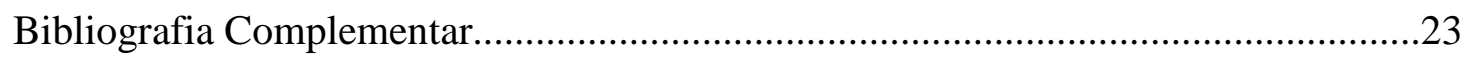

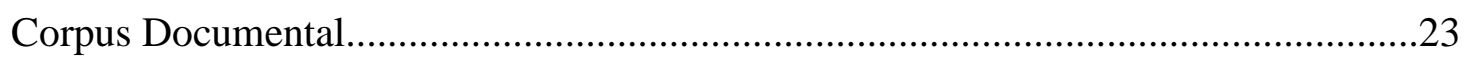

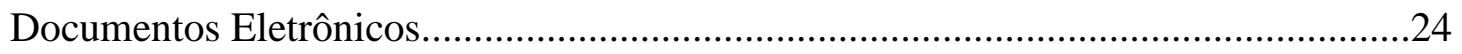

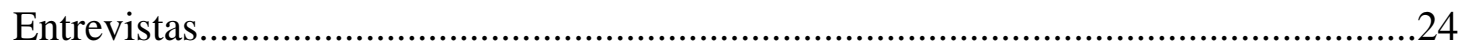

ANEXOS

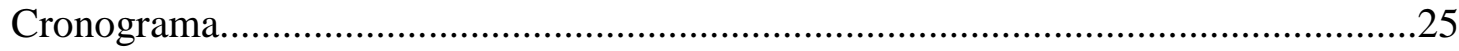

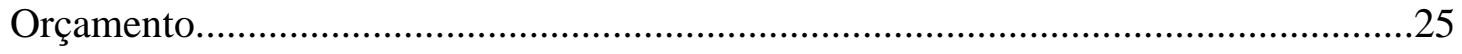

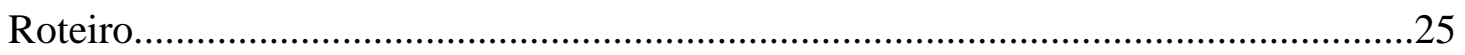




\section{INTRODUÇÃO}

O documentário, titulado Operação Brasil, pretende explicar a idéia do Projeto Rondon, o maior movimento voluntário realizado por estudantes do país e que já mobilizou mais de 400 mil universitários de 200 Instituições de Ensino Superior.

O projeto teve início em 1967, com a chamada Equipe Zero, pioneira das atividades do Projeto Rondon. O objetivo, válido até hoje, era aproximar os estudantes da realidade do Brasil e contribuir para o desenvolvimento de comunidades carentes por meio de atividades de cidadania, desenvolvimento sustentável e gestão pública. E também incentivar os universitários a conhecerem outras formas de vida, distante da universidade onde estudavam. A primeira equipe do Rondon, animada com a idéia de integração nacional, criou o lema integrar para não entregar, que significa integrar a Amazônia às outras regiões do país, antes que ela seja entregue aos estrangeiros.

O nome do projeto é uma homenagem ao Marechal Cândido Mariano da Silva Rondon, desbravador da Amazônia e defensor da integração dos povos indígenas. Foi o principal idealizador do projeto, o professor Wilson Choeri, da antiga Universidade Estadual de Guanabara - hoje Universidade do Estado do Rio de Janeiro, UERJ -, quem sugeriu o nome Rondon. Segundo Choeri, "foram esses jovens rondonistas que levaram seus pais, irmãos, amigos, namorados e até mesmo a mídia a se conscientizarem e melhor se informarem sobre a Amazônia. Ao sentirem a Amazônia, vivenciaram, apalparam, cheiraram, degustaram sua realidade",2.

Mesmo após a sua extinção como instituição pública, durante o governo de José Sarney, em 1989, o projeto continuou com as operações por meio da Associação Nacional dos Rondonistas, uma organização não-governamental presidida por Sérgio Mário Pasquali. Para Pasquali, "somando-se à já tradicional presença das Forças Armadas e da Igreja, o Projeto Rondon foi a terceira grande instituição engajada na Amazônia e no interior brasileiro, voltada para o desenvolvimento social e econômico de suas comunidades"3.

Com o apoio da UNE - União Nacional dos Estudantes - o projeto foi relançado no dia 10 de janeiro de 2005, em Tabatinga, na Amazônia, pelo presidente Luiz Inácio Lula da Silva. Apesar do apoio político, o programa é isento de qualquer doutrinação política.

\footnotetext{
${ }^{2}$ Rondon Notícias - Informativo do Projeto Rondon, Associação Nacional dos Rondonistas, Edição Especial, 40 Anos de História 1967/2007. P. 06.

${ }^{3}$ Idem. P. 04.
} 
O Projeto Rondon hoje é realizado em parceria com as universidades, as prefeituras dos municípios, o Ministério da Educação e o Ministério da Defesa. As Forças Armadas proporcionam o suporte logístico (alojamento nos quartéis, transporte, alimentação, etc.) e a segurança durante operações. Segundo Pasquali, cerca de 50 mil jovens se interessam pelo projeto, mas a capacidade de infra-estrutura para as operações é para apenas três mil estudantes.

O projeto é semelhante à Associação Civil Universidade Solidária (UniSol), criada em 1995 pela antropóloga Ruth Cardoso. A UniSol leva estudantes de universidades para localidades com baixo Índice de Desenvolvimento Humano (IDH), onde os alunos estimulam a participação da comunidade na solução de seus problemas, aliando pesquisa, extensão e experiência. As ações contribuem para o desenvolvimento social e incentivam a liderança jovem. Mais de 23 mil estudantes de 200 instituições de ensino superior já participaram da UniSol.

O enfoque do documentário é o dia-a-dia das atividades dos rondonistas durante a Operação Inverno, em julho de 2008. Mostrar o choque cultural dos estudantes da Universidade de Brasília, que saíram da capital em direção ao município de Augusto Corrêa, no interior do Pará, para conhecer uma realidade diferente da região em que vivem. Eles revelam um novo olhar sobre a cultura do norte do país, sua paisagem, culinária e costumes. Mas também percebem as necessidades daquela região: a falta de saneamento básico, de hospitais e de profissionais da área de saúde, as dificuldades de transporte, as deficiências na educação, a ausência de infra-estrutura para o turismo, o isolamento e a miséria.

O filme pretende retratar o sentimento de nacionalismo e de solidariedade dos estudantes, que não medem esforços para ajudar a população carente que encontram. Operação Brasil gira em torno da aprendizagem, das dificuldades e da nova idéia de Brasil adquirida pelos universitários durante a viagem. Também mostra a integração dos jovens com a comunidade - principalmente as crianças - e a reação dos líderes locais e de pessoas que participam das atividades. Além disso, revela o dia-a-dia dos habitantes de Augusto Corrêa e seu estilo de vida muito diferente das grandes cidades brasileiras.

Ademais, o documentário identifica os valores do Projeto Rondon e sua história por meio da voz de Sérgio Pasquali, que tem uma forte ligação com o programa. Pasquali conta com entusiasmo sua percepção sobre o projeto e emociona-se ao falar das noções de cidadania e nacionalismo que configuram o objetivo das operações. É o depoimento de quem, há 40 anos, luta pela continuidade e expansão de uma idéia que ajudou a construir. Em suas 
palavras: "a filosofia do Rondon está preservada, os velhos companheiros do Rondon têm procurado manter viva a chama do projeto".

A voz que conecta as cenas e se sensibiliza com a seqüência das imagens é da própria autora do documentário, que participou das atividades como estudante universitária. Ela entra em cena quando as imagens e as falas dos personagens são insuficientes para explicar o conteúdo significativo das situações. É a visão de uma rondonista que faz parte da história e, ao mesmo tempo, relembra os momentos vividos durante os quinze dias no interior do Pará.

Assim, o passado e o presente fundem-se por meio das narrações e da alternância dos vídeos de arquivo e fotografias em preto e branco com as gravações da experiência mais recente do Projeto Rondon, em julho de 2008. Por fim, a idéia de que o espírito de cidadania e a força de vontade da juventude universitária brasileira devem continuar, na tentativa de unificar as diferentes regiões do país e contribuir para a integração nacional. 


\section{PROBLEMA DA PESQUISA}

A questão principal do projeto é saber o significado do Projeto Rondon para a sociedade brasileira, principalmente os jovens: identificar o sentimento dos estudantes ao participarem das atividades, de que forma o programa ajuda as comunidades carentes e como ele contribui para a integração nacional.

Esses pontos centrais desencadeiam outras questões: por que o Projeto Rondon atrai tantos jovens universitários? O que eles aprendem durante as operações? Qual sua real dimensão? Quais personagens fazem parte da sua história? Como ele surgiu? Quais atores sociais são beneficiados pelo projeto? Ele realmente transmite conceitos de cidadania e nacionalismo? 


\section{JUSTIFICATIVA}

O Projeto Rondon é a maior iniciativa voluntária do país com universitários. Além dos alunos, envolve professores, militares e comunidades carentes. Muitas pessoas já ouviram falar no projeto ou conhecem alguém que já participou das atividades, mas a maioria ainda tem uma visão superficial sobre a dimensão do programa. Daí a importância de se fazer um produto que conte a história desse projeto e seu significado atual.

O trabalho é inédito porque a maioria dos filmes sobre o Projeto Rondon é de cunho pessoal, amador ou institucional. Muitos estudantes que viajam pelo programa, inclusive de comunicação social, fazem vídeos sobre o projeto. Entretanto, ainda não há nenhum material documentário que conte detalhadamente a experiência pessoal ao participar do Projeto Rondon associada ao histórico do programa. Assim, o filme é construído a partir do olhar atual de uma rondonista aliado ao olhar histórico de um dos fundadores do projeto, além da opinião dos outros integrantes da missão e de representantes do município de Augusto Corrêa. Portanto, o filme busca uma visão sensível e humanizada sobre o tema proposto.

Ademais, não há nenhum registro documentário como produto final de um estudante de Comunicação Social da Universidade de Brasília (UnB) sobre o Projeto Rondon. Dessa maneira, pretendo contribuir para o acervo da Faculdade de Comunicação da UnB com um assunto original e fomentar também o debate sobre as diferenças e semelhanças entre o documentário e o jornalismo.

Por fim, desejo apresentar o trabalho para os alunos de todos os outros cursos da Universidade de Brasília que pretendem participar do projeto e ainda não sabem exatamente o seu significado. 


\section{OBJETO E OBJETIVOS}

O objeto do trabalho é o Projeto Rondon: história, valores e experiências atuais. O objetivo é produzir o documentário Operação Brasil, de 34 minutos, que conte o significado do programa para os universitários brasileiros.

O filme também tem a objetivo de incentivar os estudantes universitários a conhecerem e participarem do projeto ou mesmo a realizarem atividades voluntárias que não estejam ligadas ao Projeto Rondon. A idéia é fazer com que os jovens percebam as diferentes realidades do país, conheçam sua diversidade cultural, passem a desejar a melhoria da qualidade de vida das comunidades carentes e façam projetos que contribuam para o desenvolvimento dessas regiões. Ademais, o trabalho pretende transmitir a idéia de integração nacional e cidadania. 


\section{REFERENCIAL TEÓRICO}

Cinema é a arte da representação, da narração e do poder emocional. O documentário é o cinema do real, busca interpretá-lo, conhecê-lo, exprimi-lo. Por meio da subjetividade, da imaginação e de um olhar sensível, geralmente mostra a simplicidade da vida e o lado humano dos acontecimentos. Muitas vezes, é a dramaturgia da própria natureza humana. Segundo Andrei Tarkovski, em Esculpir o Tempo,

toda a criação artística luta pela simplicidade, pela expressão perfeitamente simples, o que implica chegar aos niveis mais distantes e profundos da recriação da vida. (...) A luta pela simplicidade é a dolorosa busca de uma forma adequada para a verdade que se conquistou ${ }^{4}$.

A sensibilidade e a liberdade de criação permitem ao documentário fluir no tempo e espaço como em um sonho ou poesia. De acordo com Gavin Millar e Karel Reisz, no livro A Técnica da Montagem Cinematográfica,

o alto conceito de que gozam os filmes documentários, como gênero, deve-se principalmente aos que foram além da mera observação superficial e procuraram de certa forma exprimir as associações emotivas e o significado de temas naturais. ${ }^{5}$

O ponto de vista autoral e a livre invenção ao expor um tema são características que diferenciam o documentário da reportagem jornalística. De acordo com Gavin Millar e Karel Reisz, a interpretação criativa de um acontecimento natural deve, acima de tudo, preservar um pouco da espontaneidade do próprio acontecimento. Assim, o documentário tem a finalidade artística de exprimir o sentimento e o clima, e não apenas os fatos em si.

As reportagens cinematográficas (...) tratam, sobretudo, do aspecto externo dos acontecimentos; tal como uma reportagem jornalística escrita com senso de responsabilidade, selecionam as facetas mais importantes de determinada situação e apresentam-nas com isenção de ânimo. A reportagem cinematográfica não visa uma percepção estética profunda: está para o documentário genuinamente criativo como um artigo de jornal está para um trecho imaginoso de prosa ou de poesia. ${ }^{6}$

O documentário não tem a obrigação de ser uma notícia. Ele transcende o real para que continue vivo no tempo e não fica preso ao acontecimento instantâneo. Já a notícia precisa ser factual, trazer informações novas e/ou urgentes. Ela transforma um fato significativo em relato noticioso. Gavin Millar e Karel Reisz dizem ainda que a "reportagem

\footnotetext{
${ }^{4}$ TARKOVSKI, Andrei. Esculpir o Tempo. Martins Fontes, São Paulo, 1998. P. 133.

${ }^{5}$ REISZ, Karel e MILLAR, Gavin. A Técnica da Montagem Cinematográfica, Ed. Civilização Brasileira e Embrafilme, Rio de Janeiro, 1978. P. 134.

${ }^{6}$ Idem. P. 134.
} 
deve procurar mostrar somente os aspectos mais significativos de um acontecimento; o seu objetivo não é fazer um relato completo e literal". 7

Os temas chamados "frios", acontecimentos banais, corriqueiros e sem factual, geralmente têm menos importância para o jornalismo e possuem menos espaço nos jornais. Por outro lado, o documentário se interessa em captar o banal da sociedade, aquilo que não foi visto em profundidade, mas que também faz parte da cultura. Portanto, prefere buscar a verdade em seus aspectos mais banais e escondidos.

Ademais, enquanto os jornais televisivos se preocupam demasiadamente com a forma, a limpeza e a qualidade, o documentário é mais solto, livre e espontâneo. Vai além da informação ao enfatizar gestos e sons e permitir que os entrevistados se expressem mais à vontade e com mais tempo. É a contemplação humana, sem a aceleração do jornalismo. Somando-se a isso, pode haver menor manipulação no processo de filmagem e nos cortes durante a edição. De acordo com o cineasta Marcos de Souza Mendes,

essas lentes, essas câmeras, que trazem em si um coração e uma moral, ora são fixas e contemplativas; ora são móveis e participativas e correm leves e quase voam para "seguir os seres e as coisas na totalidade de seu percurso", para dialogar com outros pensamentos e olhar e ver o mundo mais em profundidade. Sem a objetividade excessiva e o oportunismo do repórter, o documentarista deixa o mundo se apresentar ${ }^{8}$.

Entretanto, o documentário tem fusões com a reportagem, principalmente com a grande reportagem - com mais profundidade e apelo emocional. Ambos possuem forças ideológicas, sociais, culturais, históricas e humanas. Enriquecem o conhecimento ao discutirem a realidade e provocam a aproximação com a própria vida do espectador, seu cotidiano e sua forma de lidar com determinados assuntos.

O documentarista é repórter quando busca a dinamicidade da vida, dá sentido às coisas e articula as diversas posições sobre um mesmo tema. Para isso, utiliza-se das técnicas jornalísticas: seleciona a pauta (o enfoque a ser abordado, as hipóteses e as perguntas que orientam a apuração), apura (processo de buscar personagens, fazer escolhas, averiguar dados, nomes, datas, números), escreve o texto (no caso do documentário, o roteiro) e edita (seleção, organização e hierarquização das informações no produto final).

A sensibilidade em busca das informações e a profundidade da apuração são estratégias de abordagem do jornalismo que também fazem parte do documentário. Ademais,

\footnotetext{
${ }^{7}$ Idem. P. 133.

${ }^{8}$ MENDES, Marcos de Souza. Cinema e Realidade: O Mundo através das Lentes. in Diálogos Cinema e Escola - MEC - Secretaria de Educação à Distância / Programa TV Escola: Salto para o Futuro, Rio de Janeiro, 2002. P. 03.
} 
os dois usam depoimentos de especialistas ou de pessoas comuns (o chamado povo fala na TV) para dar opiniões sobre determinado tema. Em seu livro Entrevista: o Diálogo Possível, Cremilda Medida diz que "a entrevista jornalística, em primeira instância, é uma técnica de obtenção de informações que recorre ao particular, por isso se vale, na maioria das circuntâncias, da fonte individualizada e lhe dá crédito, sem preocupações científicas"”. $\mathrm{O}$ documentário muitas vezes também não possui preocupação científica e se importa mais com a expressão humana em particular do que com alguma tese rígida sobre determinado assunto ou pessoa.

Cremilda Medida explica ainda as entrevistas chamadadas de neoconfissões por Edgar Morin: "o entrevistador se apaga diante do entrevistado. Este não continua na superfície de si mesmo, mas efetua, deliberadamente ou não, o mergulho interior. Alcançamos aqui a entrevista em profundidade da psicologia social" ${ }^{10}$. Esse tipo de entrevista jornalística é mais próxima à documentária, pela liberdade que o entrevistado tem para expor suas idéias mais íntimas, sem se preocupar com respostas sucintas. É o caso da entrevista com Sérgio Pasquali, em Operação Brasil, em que quase não foram necessárias perguntas. O entrevistado se debruçou ao contar a história do Projeto Rondon e revelou suas emoções e sentimentos mais profundos sobre o tema, o que possibilitou a empatia pelo espectador com o personagem do filme.

Outra técnica também comum tanto no documentário, quanto no telejornalismo, é a locução (sempre no telejornal, mas não necessariamente no documentário). Aliás, a linguagem jornalística televisiva é a mais próxima do documentário em relação aos meios impressos, uma vez que ela une imagens e sons (narrativa em off e sonoras) e faz o registro da imagem em movimento no espaço e tempo. É um texto multimodal, em que as palavras dão suporte à imagem.

Para Vera Iris Paternostro, em $O$ Texto na TV - Manual de Telejornalismo, o texto jornalístico de televisão é "coloquial, claro e preciso. Objetivo, direto. Informativo, simples e pausado"11. O documentário também precisa desses recursos para ser bem entendido pelo espectador, apesar de não ficar preso a eles.

Assim como o jornalismo, o documentário possui momentos de semelhança com a ficção, como as técnicas dos planos e cortes, necessários para o domínio de tempo e movimento. Também se utiliza das mesmas técnicas de expressão como enquadramento,

\footnotetext{
${ }^{9}$ MEDINA, Cremilda. Entrevista: o Diálogo Possível. Ed. Ática, 2002. P. 18.

${ }^{10}$ Idem. P. 15.

${ }^{11}$ PATERNOSTRO, Vera Iris. O Texto na TV - manual de telejornalismo. Ed. Brasiliense, Rio de Janeiro, 1987. P. 42.
} 
composição do campo, foco e fotometria. Além disso, o próprio envolvimento da câmera modifica o real: para filmar é preciso de espaço e luz, nem sempre disponíveis naturalmente. Sem contar que o entrevistado precisa se adaptar ao formato da câmera e pode ainda ficar constrangido ao ser filmado.

Porém, o documentário se distingue da ficção quanto ao conteúdo: não apresenta um enredo, mas expõe um tema. É claro que nem sempre isso é verdade: o documentarista pode empregar um enredo, assim como a ficção pode se utilizar de elementos documentais. Segundo Karel Reisz e Gavin Millar,

o que o diretor de documentários perde com a falta de suspense em um enredo, é compensado pela liberdade de montar os filmes de modo original e expressivo, (...) pode apresentar as facetas de seu tema e alternar a atmosfera do filme na ordem e no ritmo que desejar (...). E o mais importante: tem maior liberdade de interpretação que um diretor de filme de ficção, porque é a interpretação - a montagem - que dará vida ao seu assunto ${ }^{12}$.

Os autores dizem ainda que, no documentário, "o efeito de continuidade é obtido graças a um fluxo de idéias e de emoções"13. E vão além:

o fator principal da seleção e continuidade das cenas deveria ser o seu conteúdo emocional e seu sentido mais profundo. Quando toda a seqüência transmite a sensação e a atmosfera desejadas, e se obtêm o equilíbrio e a unidade entre a forma e o conteúdo, os valores métricos e rítmicos resolvem-se por si mesmos ${ }^{14}$.

Dessa forma, a organização dos planos deve ter uma série de justaposições expressivas que provoquem impacto emocional. Cada corte deve gerar uma nova impressão na mente do telespectador, como se houvesse um choque momentâneo na dinâmica da montagem. Por outro lado, os cortes devem ser suaves para que sejam compreensíveis.

Assim, a montagem do documentário tem que obter uma continuidade razoavelmente agradável aos olhos, ligando os planos de diferentes ritmos sem perder o fio da história, a lógica e a coerência narrativa. A montagem funciona num plano de realidade diferente daquela da narrativa direta e deve cumprir a finalidade de preencher discretamente certas lacunas da história. Para isso, são necessários elementos como ritmo e tempo. "Ritmo e fluência são uma condição prévia essencial para a montagem criativa, mesmo que não sejam fatores estéticos fundamentais"15.

\footnotetext{
${ }^{12}$ REISZ, Karel e MILLAR, Gavin, 1978, op. cit., P. 123.

${ }^{13}$ Idem. P. 159.

${ }^{14}$ Idem. P. 136.

${ }^{15}$ Idem. P. 143.
} 
Para Tarkovski, "montar um filme corretamente, com competência, significa permitir que as cenas e tomadas se juntem espontaneamente, uma vez que, em certo sentido, elas se montam por si mesmas, combinando-se segundo o seu próprio padrão intrínseco"16. Já para o diretor russo Lev Vladimirovich Kuleshov, "a arte cinematográfica começa no momento em que o diretor se põe a combinar e juntar os diversos fragmentos de um filme. Unindo-os em

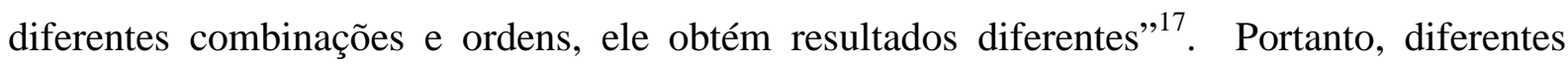
tipos de montagem sugerem interpretações e conclusões intelectuais distintas.

Segundo Karel Reisz e Gavin Millar, a fim de conseguir melhores efeitos, o montador precisa se ater a alguns pontos fundamentais:

1) manter claro para o espectador o "enredo" da seqüência, isto é, evitar que a montagem alternada prejudique a continuidade; 2) variar a rapidez dos cortes de modo a obter as mudanças desejadas na tensão dramática; 3) cortar para planos de reação de observadores imóveis para preencher os lapsos de tempo entre planos de ação adjacentes, e para orientar a reação emocional do espectador; 4) manter variedade visual e dar a ilusão de movimento contínuo pelo emprego freqüente da montagem alternada e pela variação dos pontos de vista de um mesmo trecho de ação ${ }^{18}$.

No documentário Operação Brasil, apesar de ter uma só câmera disponível para as filmagens, as cenas nem sempre aparecem em planos longos. Isso porque, com as técnicas de edição, pude colocar o off em planos filmados em tempos diferentes do real. Assim, o espectador pode perceber os detalhes significativos de uma mesma cena em cortes distintos; e cada plano transmite um dado novo e específico.

Para dar ênfase a certos trechos da narrativa, faz-se a escolha de detalhes que intensificam a emoção. "O simples aparecimento da imagem ampliada significa, para o espectador, que chegou um momento de maior intensidade dramática"19. Em Operação Brasil, o close no olhar do Sargento Soares, quando ele se emociona com a despedida dos rondonistas, aproxima o personagem do espectador e simboliza um momento de profunda expressão. De acordo com Marcel Martin, em A Linguagem Cinematográfica, "é no primeiro plano do rosto humano que se manifesta melhor o poder de significação psicológico e dramático do filme". ${ }^{20}$

A duração dos planos também ajuda no controle do impacto de uma cena. No começo de Operação Brasil, os jovens falam apenas uma frase ou palavra sobre a região de onde

\footnotetext{
${ }^{16}$ TARKOVSKI, Andrei, 1998, op. cit., P. 136.

${ }^{17}$ REISZ, Karel e MILLAR, Gavin, 1978, op. cit., P. 21.

${ }^{18}$ Idem. P. 79.

${ }^{19}$ Idem. P. 15.

${ }^{20}$ MARTIN, Macel. A Linguagem Cinematográfica, Ed. Itatiaia, 1963. P. 39.
} 
vieram ou para onde vão, e a seqüência dos cortes é acelerada para dar a noção de amplitude do projeto, o que gera a impressão de aumento da carga emotiva até chegar ao clímax.

$\mathrm{O}$ espectador também se sensibiliza quando cria uma empatia com o personagem e compartilha seus pensamentos mais profundos. Assim, "a motivação das ações dos personagens podiam tornar-se mais claras se o espectador pudesse ver certos pensamentos ou recordações passarem pela sua mente" ${ }^{, 21}$. Os filmes de arquivo e as fotografias antigas mostradas em Operação Brasil, enquanto Sérgio Pasquali relembra a história do Projeto Rondon - que também faz parte de sua própria história -, simbolizam a memória de Pasquali. Essa memória trazida ao tempo real aproxima o espectador do pensamento do personagem.

Ademais, os documentos de arquivo em preto-e-branco realçam a verossimilhança histórica. Segundo Marcel Martin,

\begin{abstract}
é possível conceber a coexistência do preto-e-branco e da cor no mesmo filme em razão das implicações psicológicas de um e de outro. (...) A cor pode ter um eminente valor psicológico dramático. Assim, sua utilização bem compreendida pode ser não apenas uma fotocópia do real exterior, mas preencher igualmente uma função expressiva e metafórica, da mesma forma que o preto-e-branco é capaz de traduzir e dramatizar a luz. ${ }^{22}$
\end{abstract}

Assim, o documentário Operação Brasil utiliza-se de diversos elementos que reforçam a expressão e auxiliam na formação de significados. Conclui-se, portanto, que as técnicas cinematográficas são fundamentais para a construção do documentário. Entretanto, não basta o domínio da técnica, é preciso ter sensibilidade ao fazer escolhas e deixar a realidade mostrar-se diante da câmera.

\footnotetext{
${ }^{21}$ REISZ, Karel e MILLAR, Gavin, 1978, op. cit., P. 14.

${ }^{22}$ MARTIN, Macel, 1963, op. cit., P. 70 e P. 71.
} 


\section{METODOLOGIA}

A primeira etapa do trabalho foi a pesquisa bibliográfica inicial sobre o Projeto Rondon: quando foi criado, onde, como, por quem e por que. Conversei informalmente com professores que participam do projeto e busquei na página do Ministério da Defesa na Internet $^{23}$ informações históricas e também administrativas, como o funcionamento e a logística para a realização das chamadas Operações Nacionais.

Durante o primeiro semestre de 2008, fui aluna da disciplina Formação Teórica Sobre a Ação e Concepção do Projeto Rondon, do Decanato de Extensão da Universidade de Brasília - UnB. Assim, pude ver muitos vídeos e fotografias de estudantes que participaram do projeto em operações passadas e percebi a ausência de um filme mais elaborado, que explicasse melhor o trabalho desenvolvido nas comunidades e o sentimento dos rondonistas em cada momento da viagem.

As aulas me ajudaram também a entender os procedimentos necessários para a realização do trabalho em equipe e o funcionamento do Projeto Rondon. Ademais, a própria noção de voluntariado era transmitida quando os colegas de classe se entusiasmavam com novas idéias e buscavam saber mais detalhadamente sobre a situação do município em que iriam trabalhar.

Depois de ser selecionada para a viagem da Operação Inverno, em julho deste ano, com destino ao município de Augusto Corrêa, no Pará, pedi apoio e autorização para a realização do trabalho aos professores que iriam viajar na minha equipe.

Após a autorização, preparei todo o aparato necessário para as gravações. Primeiro, procurei informações técnicas com cinegrafistas profissionais e professores da universidade sobre o uso da câmera. Como o estado do Pará possui alta umidade, pedi orientação sobre cuidados com o equipamento - evitar locais com ar condicionado, não guardar a câmera em saco plástico e, se for o caso, usar um secador de cabelo para secar a filmadora.

Além de preparar os equipamentos - câmera, baterias, carregador, microfone, e tripé -, organizei um material com informações sobre o Projeto Rondon para consulta durante a viagem. Também fiz um rascunho com idéias de seqüências, cenas e entrevistas. Preferi não esquematizar detalhadamente, pois o objetivo era seguir o rumo dos acontecimentos e, depois de encarar a realidade, tirar as conclusões sobre a história que o documentário iria contar. Assim, não fiz um roteiro prévio e achei melhor ficar à espera dos acontecimentos.

\footnotetext{
${ }^{23}$ http://www.defesa.gov.br
} 
Desde o primeiro dia da viagem, preocupei-me em flagrar cada momento significativo. O objetivo era captar imagens naturais e espontâneas dos rondonistas, com a menor intervenção possível. Além de manter a câmara ligada durante as atividades dos estudantes, preocupe-me em fazer imagens de paisagens e planos gerais do município para captar a cultura e os costumes locais. Também entrevistei agentes públicos a fim de conseguir depoimentos sobre o trabalho desenvolvido pelos rondonistas na cidade de Augusto Corrêa. Durante os 15 dias de viagem, usei 12 fitas Mini DV (cada uma armazena 60 minutos de vídeo) para as gravações.

Além das filmagens, pedi para a prefeitura e para as secretarias municipais todas as informações sobre o município: dados sobre educação, população, economia, localização, saneamento básico, cultura, turismo, clima, entre outros. Também fiz anotações pessoais sobre os aspectos típicos da região e sobre o dia-a-dia dos rondonistas em um diário de bordo, que me auxiliou depois a lembrar dos detalhes da viagem.

Escrever no blog do Projeto Rondon de 2008, na página da Universidade de Brasília na Internet ${ }^{24}$, enquanto participava da operação, também me ajudou a formar uma opinião mais concreta sobre o programa.

A próxima etapa, já em Brasília, foi preparar a parte histórica sobre o Projeto Rondon. Conversei com agentes que trabalham na administração do Rondon, como o secretário executivo da Associação Nacional dos Rondonistas, Estanislau Oliveira, e um dos conselheiros do projeto, Luiz Ribeiro de Mendonça. Em seguida, entrevistei um dos criadores do programa, Sérgio Pasquali, que me contou a história e a evolução do projeto (usei duas fitas Mini DV para a entrevista). Pasquali me emprestou seu acervo pessoal sobre o Projeto Rondon: fotografias, documentos e jornais. Copiei as imagens para usá-las no bloco histórico do documentário.

O próximo desafio era conseguir filmes de arquivo sobre o projeto. Os Centros de Documentação (Cedoc) da TV Globo e da UnB TV me autorizaram a fazer as pesquisas de imagens e as cópias dos arquivos.

Depois de juntar todos os dados disponíveis, fiz o visionamento do material bruto e a decupagem do material gravado. Em seguida, criei uma primeira estrutura visual (partes, seqüências, cenas, planos) e comecei a elaborar um roteiro prévio, com seleção e exclusão de cenas. No final, escrevi o off, selecionei fotos e documentos de arquivo para usar no documentário.

\footnotetext{
${ }^{24} \mathrm{http}: / /$ www.unbrondon2008.blogspot.com
} 
A última fase foi a montagem do material e a edição em um documentário de 34 minutos. Esta etapa incluiu a finalização da arte e dos créditos, as correções técnicas de imagem e a sincronização do som.

Durante a produção de todas as etapas, também fiz leituras de textos e livros sobre cinema, documentário e jornalismo, que me ajudaram a entender melhor as técnicas para a construção de um filme e a diferença entre a grande reportagem e o documentário. Também contei com a ajuda do professor David Renault, que contribuiu para a realização do trabalho com sugestões, correções e apoio logístico. Os professores Marcos Mendes e David Pennington me auxiliaram na parte prática e teórica da construção do documentário. 


\section{CONCLUSÕES}

Saber o real significado do Projeto Rondon para a sociedade brasileira é uma questão que exige muito mais do que um esforço pessoal. É preciso perguntar a todos aqueles que vivenciaram o projeto e ajudaram a construí-lo o que eles sentem ao participarem das operações. Qual o sentimento que liga essas pessoas que se conhecem muito pouco em um mesmo objetivo, em uma mesma sintonia.

Ao viajar para a Operação Inverno, em julho passado, construí uma visão bem particular sobre o projeto, já que meu destino era um município específico e cada região traz uma realidade diferente da outra. Entretanto, ao voltar de viagem, ou mesmo durante o encontro com outras equipes em Belém, percebi que não importa o quão distante eu estava dos outros grupos. A emoção que sentíamos sobre o projeto era a mesma.

Cariocas, paulistas, mineiros, goianos, paranaenses. Todos saíram de suas cidades com o mesmo objetivo: ajudar comunidades carentes com projetos de educação, cidadania e gestão pública. E voltaram praticamente com a mesma sensação de dever cumprido, apesar das dificuldades.

Todo esse sentimento comum se refletiu no meu filme, já que não fui um corpo estranho diante dos acontecimentos. Estava lá, vivenciando cada instante, sem deixar a filmadora de lado. E isso foi essencial para a construção do documentário, já que esse tipo de filme é muito mais solto, leve e natural. O documentário deixa as coisas acontecerem, sem se preocupar em mudar a realidade.

Dessa forma, meu objetivo era apenas deixar a realidade se mostrar diante de mim, uma realidade bastante distante da minha. Para isso, observei o comportamento das pessoas, suas atividades, seu cotidiano, sua maneira de se vestir e de se comunicar. Aproximei-me dos entrevistados com discrição e deixei as pessoas darem sua opinião, sem tentar influenciá-las. Mas também interagi no meio em que estava inserida: participei dos acontecimentos, fiz perguntas e tirei dúvidas para compreender melhor o modo de vida daquela comunidade. Assim, fui repórter, personagem e narradora e contei no documentário minha própria vivência, sensações e impressões. É o que o jornalismo chama de observação participante. Apesar da participação do jornalista nos acontecimentos, ele mantém a isenção pretendida pela profissão: não mente, não distorce, nem cria fatos inexistentes. Por outro lado, a objetividade no jornalismo é controversa, já que toda experiência humana depara-se com a subjetividade. 
A partir da experiência pessoal e das entrevistas, o objetivo de criar um documentário que mostrasse cada aspecto do projeto, desde seu surgimento até os dias atuais foi superado. A idéia de divulgar não só as atividades dos rondonistas, mas também a cultura local e o sentimento geral de quem participa das operações foi exposta de forma satisfatória. Consegui captar as minúcias do projeto, sem deixar escapar seus valores principais.

O filme é inédito porque apresenta o Projeto Rondon sobre vários aspectos de forma criativa e natural. Dessa maneira, cumpre a função de incentivar os estudantes universitários a conhecerem e participarem do projeto, além de fazer com que eles percebam as diferentes realidades do país e desejem a melhoria da qualidade de vida das comunidades carentes. $\mathrm{O}$ objetivo de transmitir a idéia de integração nacional e cidadania também foi alcançado.

O desafio de filmar praticamente sozinha foi superado aos poucos. No começo, a dificuldade de carregar a máquina, o tripé e todo o material que usaria durante as atividades do projeto. Mas, depois de um tempo, a própria equipe que me acompanhou passou a sentir que a câmara havia se transformado em um elemento fundamental ao nosso trabalho.

Pela primeira vez, fiquei tanto tempo segurando uma filmadora. Pela primeira vez, fiz uma produção audiovisual sozinha, incluindo as filmagens, o roteiro e a direção. Pela primeira vez, busquei a diferença entre o jornalismo e o documentário. E tive grandes dificuldades em superar essa diferença, já que estava tão acostumada com o formato do jornalismo. Entretanto, o projeto não deixou de ter elementos jornalísticos e nem era meu objetivo fugir totalmente desses elementos.

Por outro lado, aprender a fazer um documentário, algo novo para uma estudante de jornalismo, foi uma experiência que me ajudou bastante a entender melhor até mesmo a profissão que escolhi seguir. Descobri que muitos instrumentos usados no documentário se assemelham aos do jornalismo e aos do filme de ficção. Mas também notei as diferenças fundamentais que definem cada um deles.

Portanto, a experiência de fazer algo novo, diferente do que havia feito durante os quatro anos em que cursei Comunicação Social na UnB, foi muito importante para o meu crescimento pessoal como estudante de comunicação. Busquei ir além do que já tinha aprendido e fui atrás de algo que desconhecia. Assim, com a criação de um filme, acredito que a minha formação ficou mais completa.

A união das técnicas cinematográficas com o tema "Projeto Rondon" resultou em um documentário com a visão autoral de quem fez parte dos acontecimentos e resolveu registrálos pela emoção que geravam. Uma emoção compartilhada com milhares de estudantes pelo 
Brasil afora. Dividir esse sentimento e revelá-lo para a sociedade, a fim de unir um brasileiro da região sul a outro da região norte, é a função do meu documentário.

Uma equipe do Projeto Rondon de Mato Grosso escreveu, em 1969, a seguinte mensagem, com a qual encerro meu texto:

Não basta olhar o mapa do Brasil aberto sobre a mesa de trabalho ou pregado a parede de nossa casa. É preciso andar sobre ele, sentir de perto as angústias do povo, suas esperanças, seus dramas ou suas tragédias, sua historia, sua fé no destino da nacionalidade. Só então se compreenderá que a responsabilidade dessa geração é simplesmente formidável. Tudo indica, porém, que agora começou, para alegria nossa, a batalha longamente esperada da integração dos nossos irmãos abandonados na comunhão nacional. 


\section{BIBLIOGRAFIA}

\section{BIBLIOGRAFIA REFERENCIADA}

- MARTIN, Macel. A Linguagem Cinematográfica, Ed. Itatiaia, 1963;

- MEDINA, Cremilda. Entrevista: o Diálogo Possível. Ed. Ática, 2002;

- MENDES, Marcos de Souza. Cinema e Realidade: O Mundo através das Lentes, in Diálogos Cinema e Escola - MEC - Secretaria de Educação à Distância / Programa TV Escola: Salto para o Futuro, Rio de Janeiro, 2002;

- PATERNOSTRO, Vera Iris. O Texto na TV-manual de telejornalismo. Ed. Brasiliense, Rio de Janeiro, 1987;

- REISZ, Karel e MILLAR, Gavin. A Técnica da Montagem Cinematográfica, Ed. Civilização Brasileira e Embrafilme, Rio de Janeiro, 1978;

- TARKOVSKI, A. Esculpir o Tempo. Martins Fontes, São Paulo, 1998.

\section{BIBLIOGRAFIA COMPLEMENTAR}

- MOTTA, Aricildes de Moraes. História Oral do Projeto Rondon, Biblioteca do Exército, Rio de Janeiro, 2006.

- Projeto Rondon e sua Dimensão Atual, Ed. do Ministério do Interior, Brasília, 1974.

\section{CORPUS DOCUMENTAL}

- Rondon Notícias - Informativo do Projeto Rondon, Associação Nacional dos Rondonistas, Ano X, No 11, 2007;

- Rondon Notícias - Informativo do Projeto Rondon, Associação Nacional dos Rondonistas, Edição Especial, 40 Anos de História 1967/2007;

- Rondon Notícias - Informativo do Projeto Rondon, Associação Nacional dos Rondonistas, Ano XI, No 12, 2008;

- Centro de Documentação da TV Globo;

- Centro de Documentação da UnB TV;

- Acervo de documentos de Sérgio Pasquali. 


\section{DOCUMENTOS ELETRÔNICOS}

- http://www.defesa.gov.br;

- http://www.unbrondon2008.blogspot.com.

\section{ENTREVISTAS}

- Estanislau Oliveira, secretário executivo da Associação Nacional dos Rondonistas;

- Luiz Ribeiro de Mendonça, conselheiro do Projeto Rondon;

- Sérgio Mário Pasquali, presidente da Associação Nacional dos Rondonistas. 


\begin{abstract}
ANEXOS

\section{CRONOGRAMA}

- Junho: pesquisa bibliográfica inicial.

- Julho: trabalho de campo, gravações e filmagens.

- Agosto: decupagem, pesquisa bibliográfica, leitura e últimas entrevistas.

- Setembro, outubro e novembro: montagem, edição e finalização.
\end{abstract}

\title{
ORÇAMENTO
}

A participação no Projeto Rondon, em julho de 2008, como rondonista não teve custeio. Já para as gravações, gastei 14 fitas mini DV no valor de 10 reais cada, totalizando 140 reais. Para a montagem, paguei $\mathrm{R} \$ 300,00$ à editora. Para a capa, $\mathrm{R}$ \$ 3,60 por página de impressão (com duas impressões), $\mathrm{R} \$ 1,00$ por DVD e $\mathrm{R} \$ 0,90$ por capa. Total dos custos: $\mathrm{R} \$ 467,50$.

\section{ROTEIRO}

\begin{tabular}{|l|l|}
\hline \multicolumn{1}{|c|}{ IMAGEM } & ÁUDIO \\
\hline FITA $5 * *$ 00 43 POSE PARA BIG & SOBE SOM \\
FITA 5255 MARCO NA PORTA DA & \\
CASA E PESSOAS PASSANDO & \\
FITA $6 * *$ SELVA! 15 20 GALERA JOGANDO & \\
FUTEBOL & \\
$* * * * *$ FITA 4 - 624 IMAGEM LINDA & \\
DO MENINO RINDO E GRITANDO & \\
FITA $4 * * 15$ 12 CARONA DO SACI & \\
FITA $4 * * 1237$ ÍNDIA RINDO & \\
FITA 8 - ** 21 00 MENINA NA & \\
JANELA & \\
\hline
\end{tabular}




\begin{tabular}{|c|c|}
\hline $\begin{array}{l}\text { FITA } 8 \text { - **21 } 00 \text { MENINA CLOSE } \\
\text { ESCONDIDA } \\
\text { FITA } 4 * * 2035 \text { LEGAL, CLOSE } \\
\text { QUEIMADA } \\
\text { FITA } 4 \text { - } 445 \text { SACI JOGANDO BOLA E } \\
\text { BARCO NO FUNDO } \\
\text { - FITA } 5 * * 146 \text { CRIANÇAS FAZEM } \\
\text { POSE PARA SEREM FILMADAS } \\
\text { IMAGENS DAS CRIANÇAS }\end{array}$ & $\begin{array}{l}\text { FITA } 6 \text { - CARTAS: } \\
1927 \text { CARTA DA NAISA, QUERIDA } \\
\text { AMIGA MEU NOME É NAISA, } \\
\text { TENHO } 12 \text { ANOS, MORO EM NOVA } \\
\text { OLINDA, } \\
2115 \text { AQUI EM NOVA OLINDA TEM } \\
\text { BASTANTE FRUTAS TALVEZ EU } \\
\text { POSSA MANDAR ALGUMAS PRA } \\
\text { VOCÊ } \\
\text { FITA } 6 \text { - } 18 \text { 50 EU NÃO TE CONHEÇO, } \\
\text { NEM SEI SEU NOM, MAS É MUITO } \\
\text { BOM FAZER AMIGOS, } \\
2321 \text { - CARTA DA MARIEL- MANDO } \\
\text { UM VERSO PARA VOCÊ, AMIGAS } \\
\text { COMO AMIGAS, AMIGAS VAMOS } \\
\text { SER, AMIGAS PARA SEMPRE,, } \\
\text { AMIGAS DE MORRER, OBRIGADO } \\
2221 \text { MENINA COM VERGONHA } \\
\text { COM PAPEL NA CARA. } 2221 \\
\text { MENINA COM VERGONHA COM } \\
\text { PAPEL NA CARA. GOSTARIA DE } \\
\text { CONHECER VOCÊ, E QUERIA SABER } \\
\text { COMO É SEU NOME, E ONDE VOCÊ } \\
\text { MORA, E QUERO SABER QUANTOS }\end{array}$ \\
\hline
\end{tabular}




\begin{tabular}{|c|c|}
\hline $\begin{array}{l}\text { FITAS } 5 \text { E } 7 \text { - PAISAGENS } \\
\text { PERFEITAS - } 618 \text { - ATÉ O FINAL } * * 6 \\
27 \text { BARCO ENCOSTA NOS OUTROS } \\
\text { BARCOS, CACHORRO CORRENDO ** } \\
1220 \text { RONDONISTAS EM DIREÇÃO } \\
\text { AO IGARAPÉ } \\
644 \text { PERFEITO, SOL ACABANDO, } \\
\text { ESCURO NO FUNDO } * * 710 \text { ESCURO } \\
\text { NO FUNDO } * * 726 \text { HOMEM } \\
\text { SOZINHO NO BARCO, PARECE } \\
\text { ISOLADO NA VASTIDÃO ** } 744 \\
\text { PERFEITA DO CÉU E DEPOIS DESCE } \\
* * 822 \text { MENINO CARRINHO DE MÃO } \\
\text { E DEPOIS HOMEM DE BICICLETA E } \\
\text { DEPOIS OUTRO HOMEM }\end{array}$ & $\begin{array}{l}\text { ANOS VOCÊ TEM, } \\
\text { **21 } 36 \text { QUERIDO AMIGO, SOU } \\
\text { ANTÔNIO MARCOS, TENHO } 11 \\
\text { ANOS E ESTOU NA QUINTA SÉRIE, } \\
\text { JUNTO COM O PROJETO RONDON, } \\
\text { MANDO ESTA CARTA PARA VOCÊ, } \\
\text { ESTOU EM NOVA OLINDA, EM } \\
\text { BRAGANÇA BELÉM DO PARÁ, } \\
\text { MESMO ESTANDO TÃO LONGE, } \\
\text { SOMOS AMIGOS, VOU FALAR COMO } \\
\text { É MEU DIA A DIA NO PARÁ, DE } \\
\text { MANHA UM CAFÉ COM UM PÃO } \\
\text { TÃO GOSTOSO, UM ALMOÇO COM } \\
\text { PEIXE, A NOITE BRINCAMOS E } \\
\text { DORMIMOS E TEM UM AÇAÍ, NEM } \\
\text { TE CONTO, ENFIM, ATÉ, ABRAÇO. } \\
\text { ANTONIO MARCOS. } \\
\text { MÚSICA DE ENTRADA “MAZURCA } \\
\text { DO VIAJOR”, DE ROBERTO CORRÊA }\end{array}$ \\
\hline
\end{tabular}




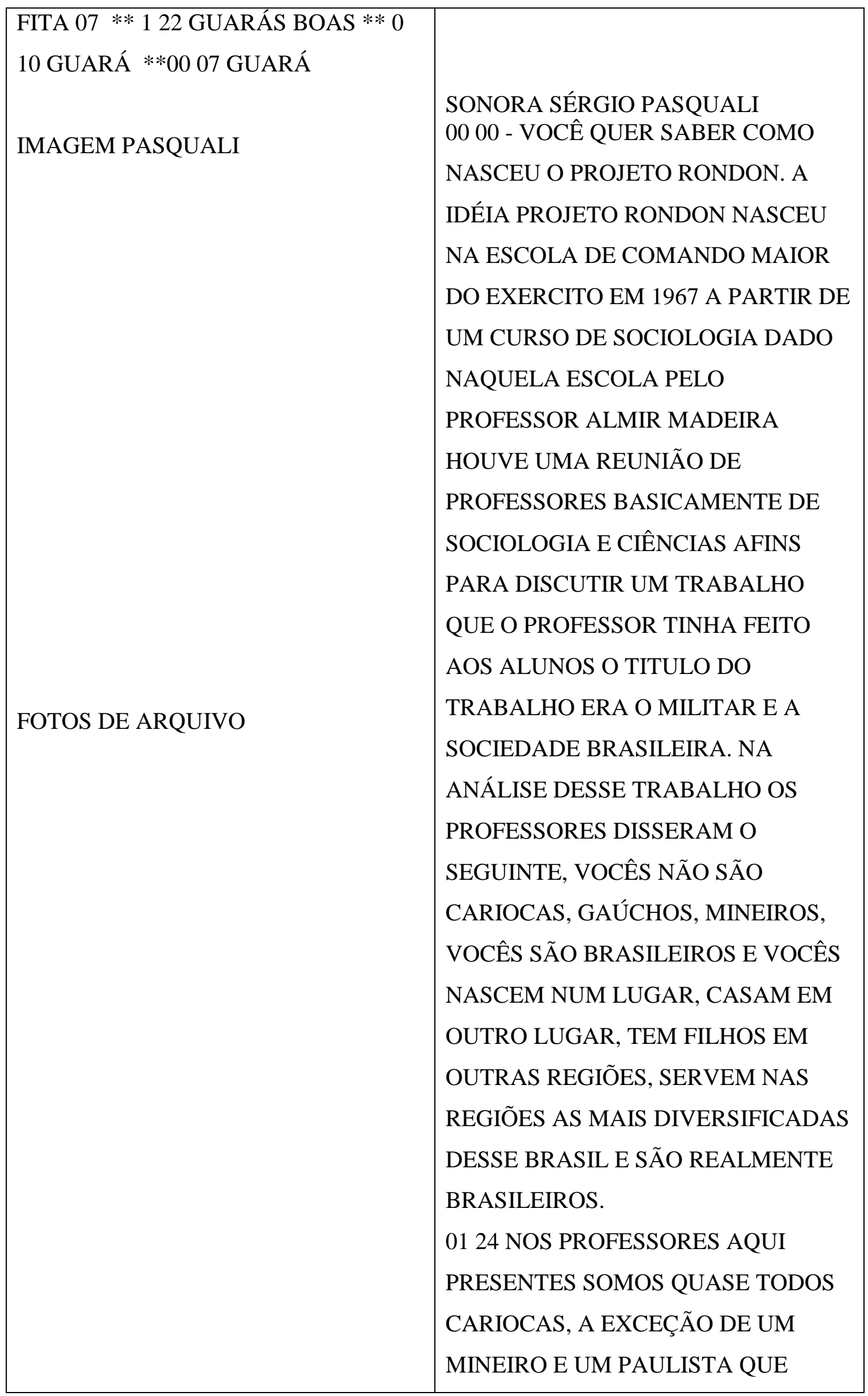




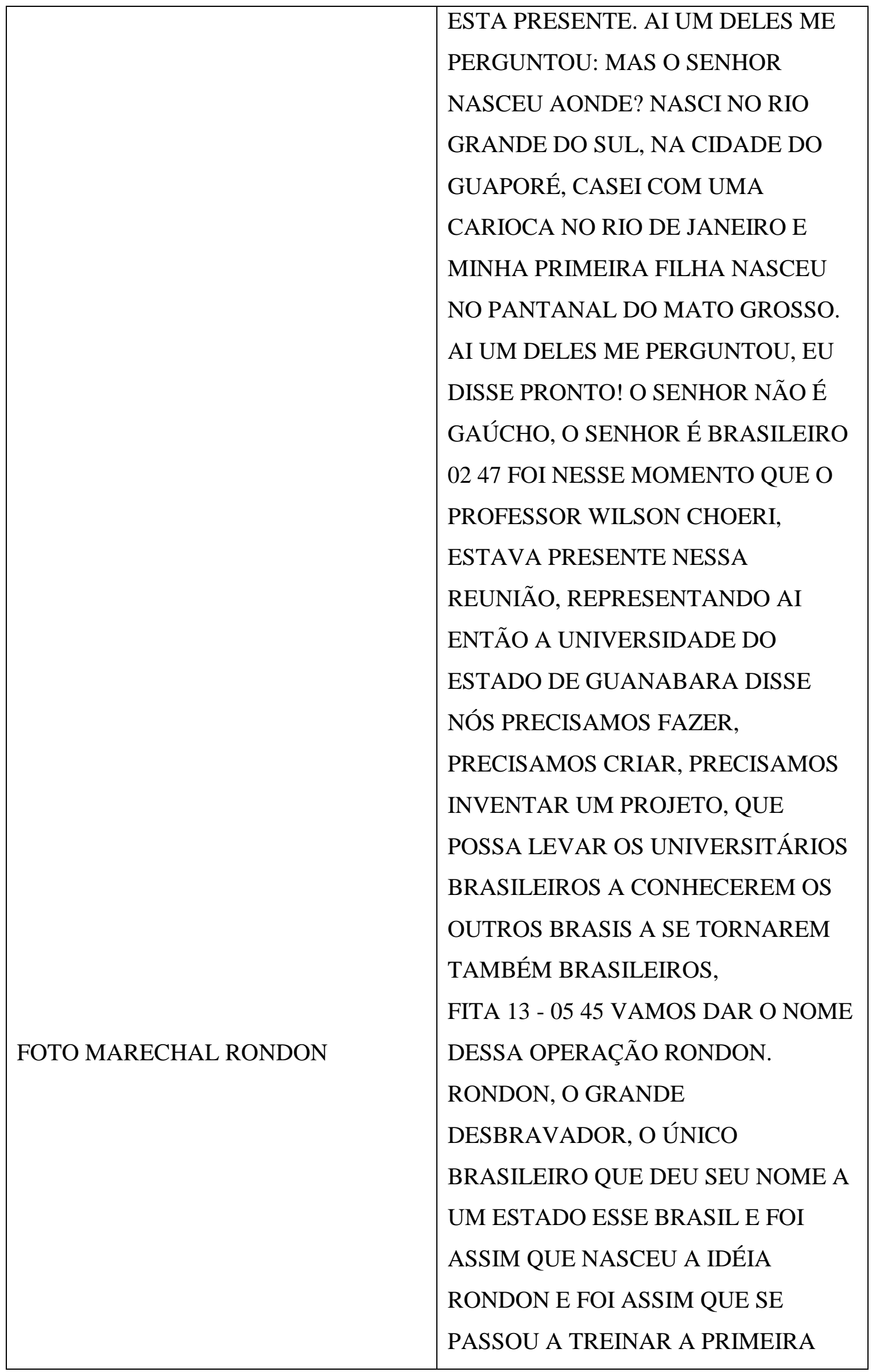




\begin{tabular}{|c|c|}
\hline $\begin{array}{l}\text { IMAGENS ESTUDANTES } \\
\text { FITA2: } \\
450-739-844-2034-2051-1504 \text { - } \\
1521\end{array}$ & 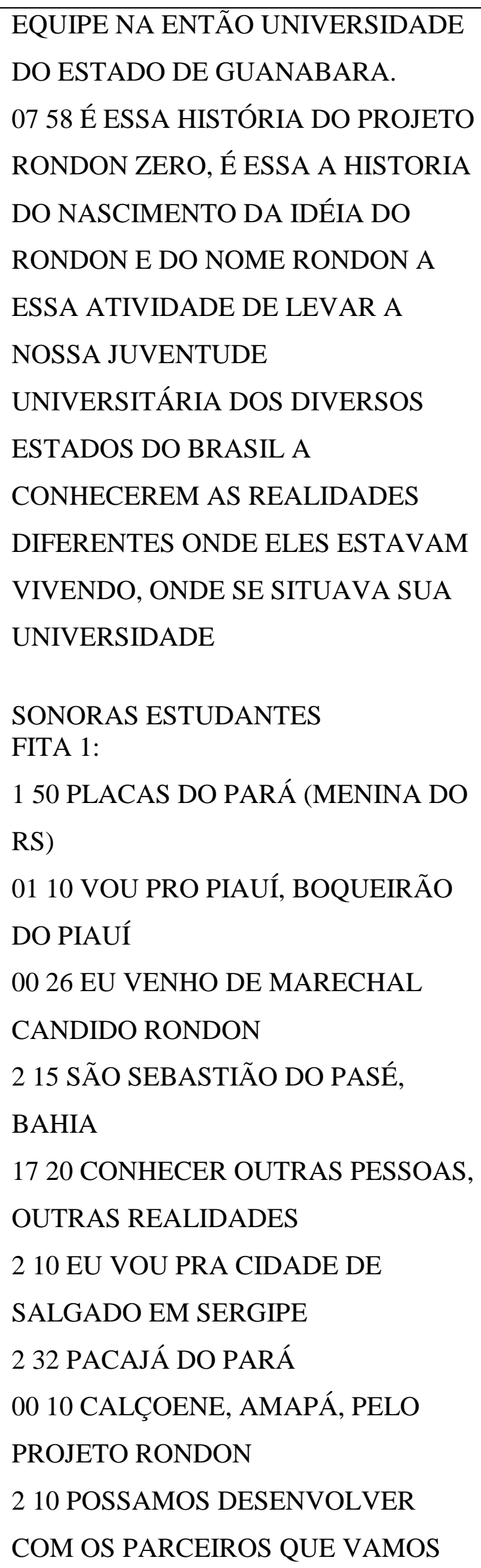 \\
\hline
\end{tabular}




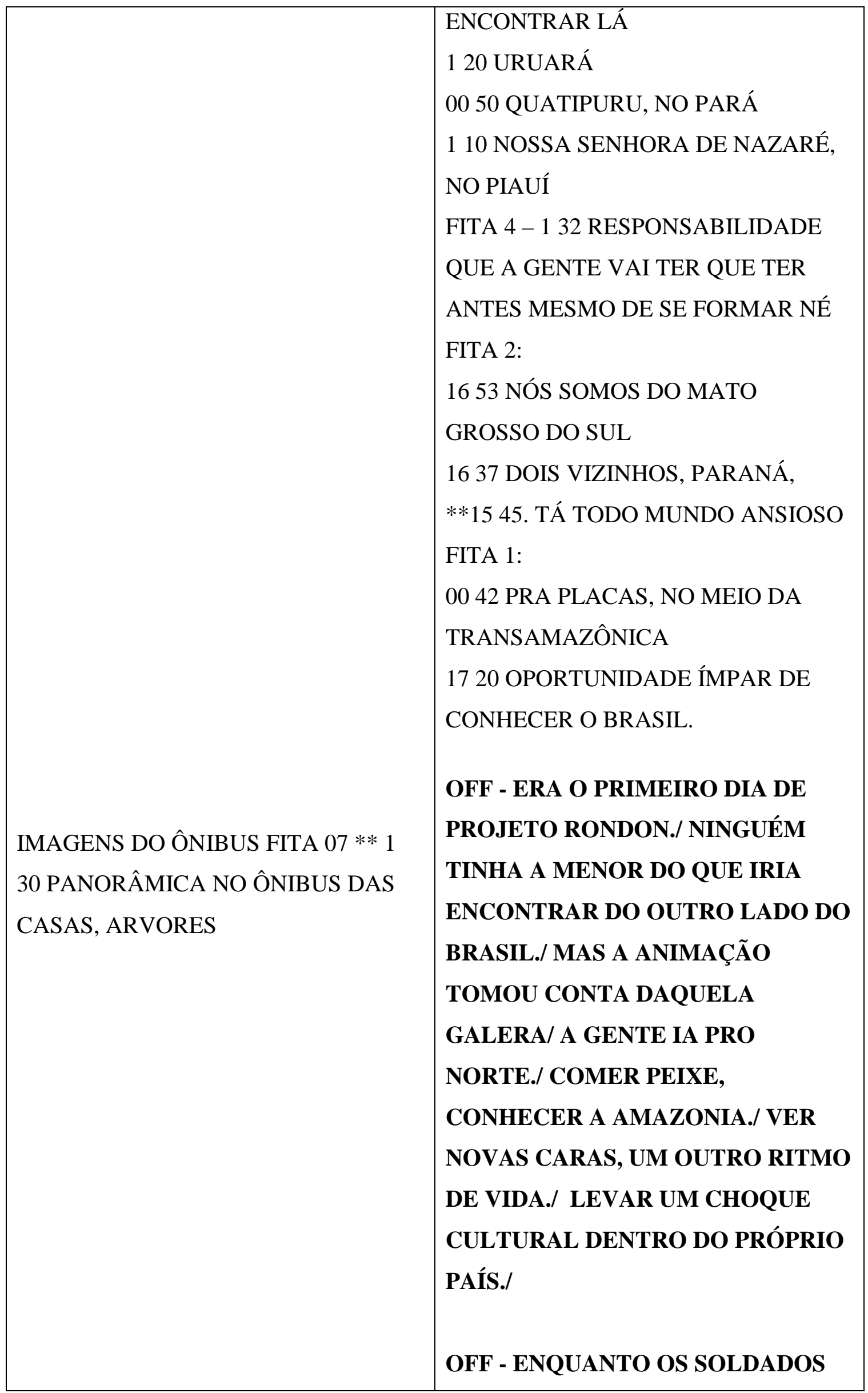




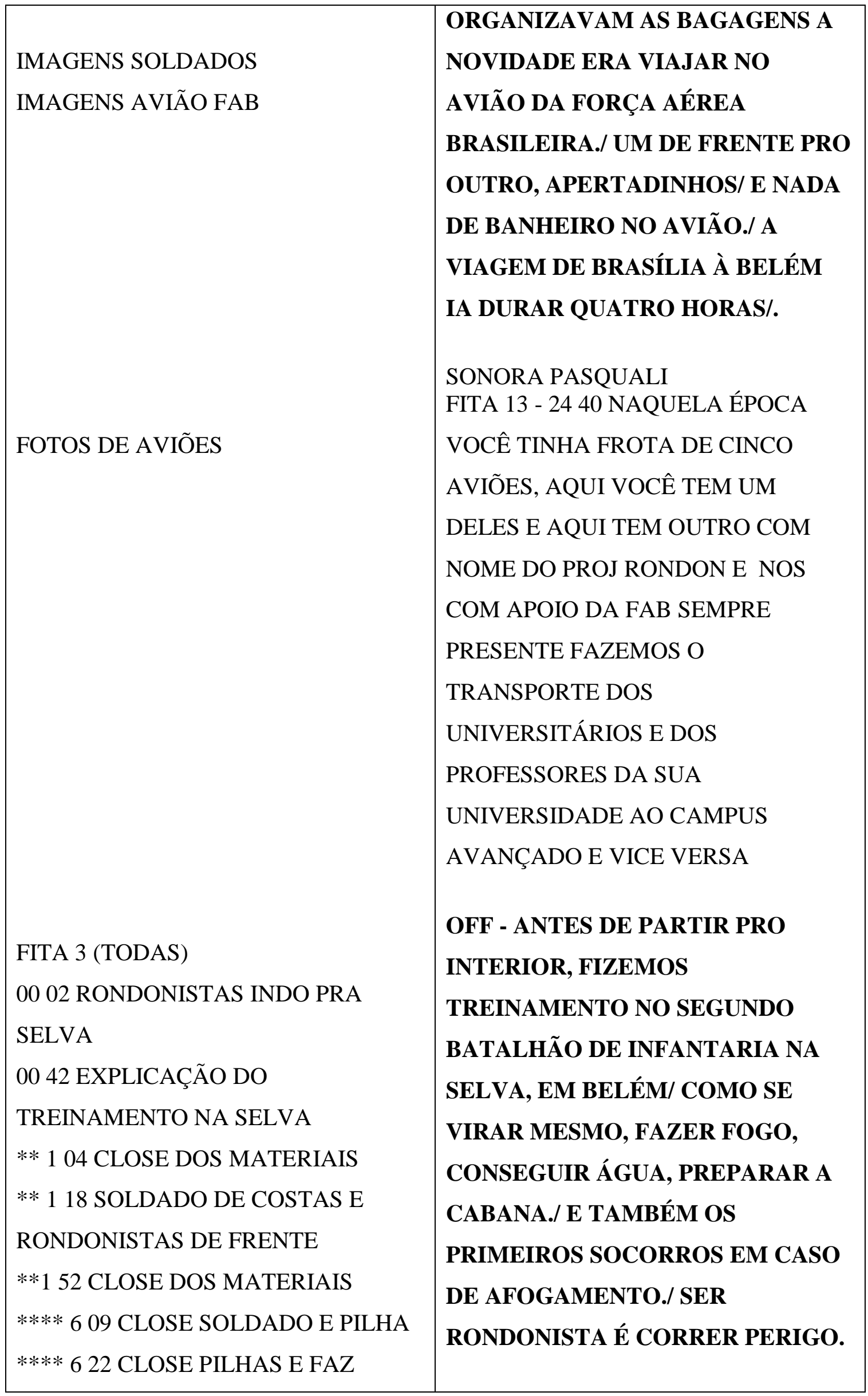




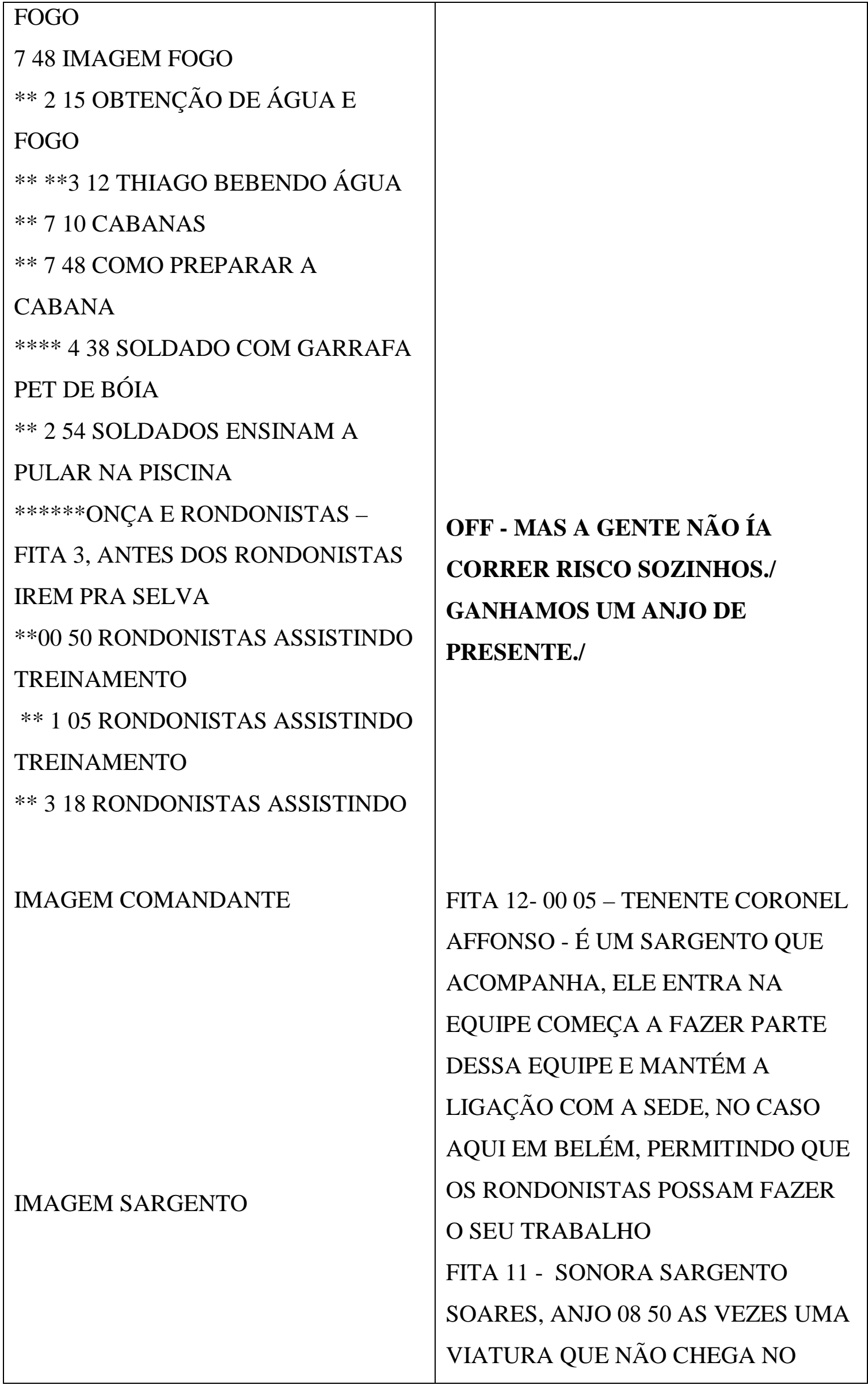




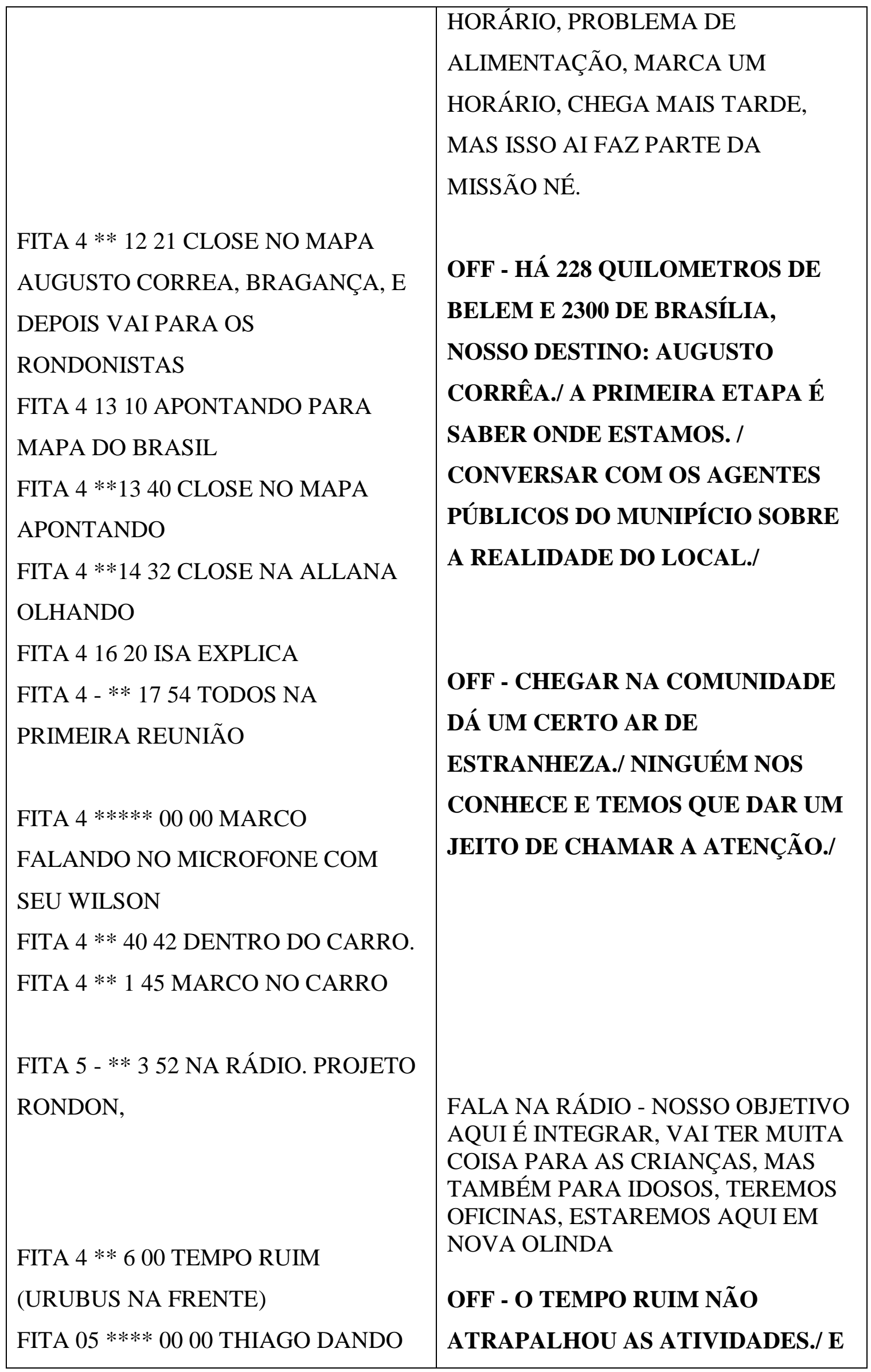




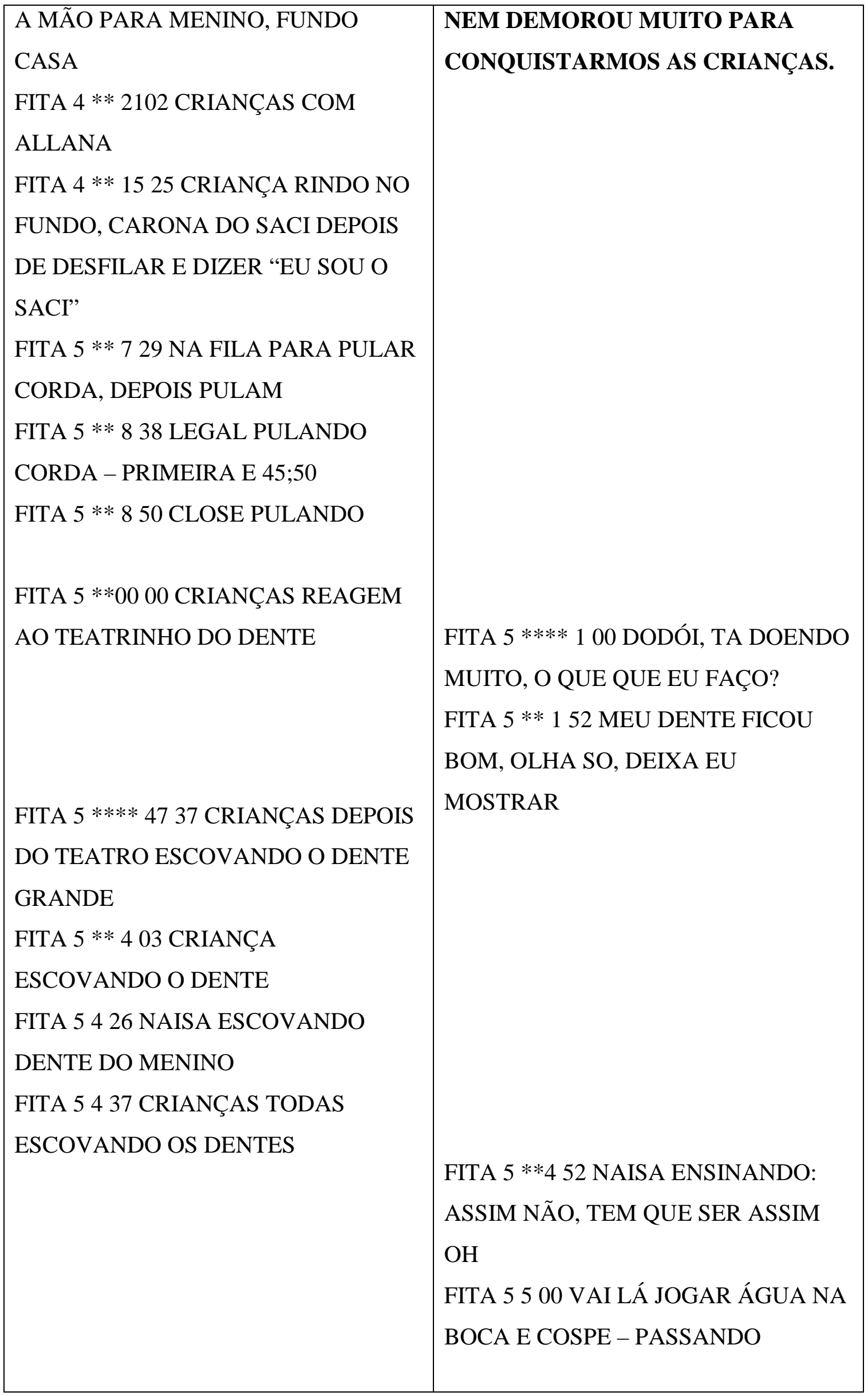




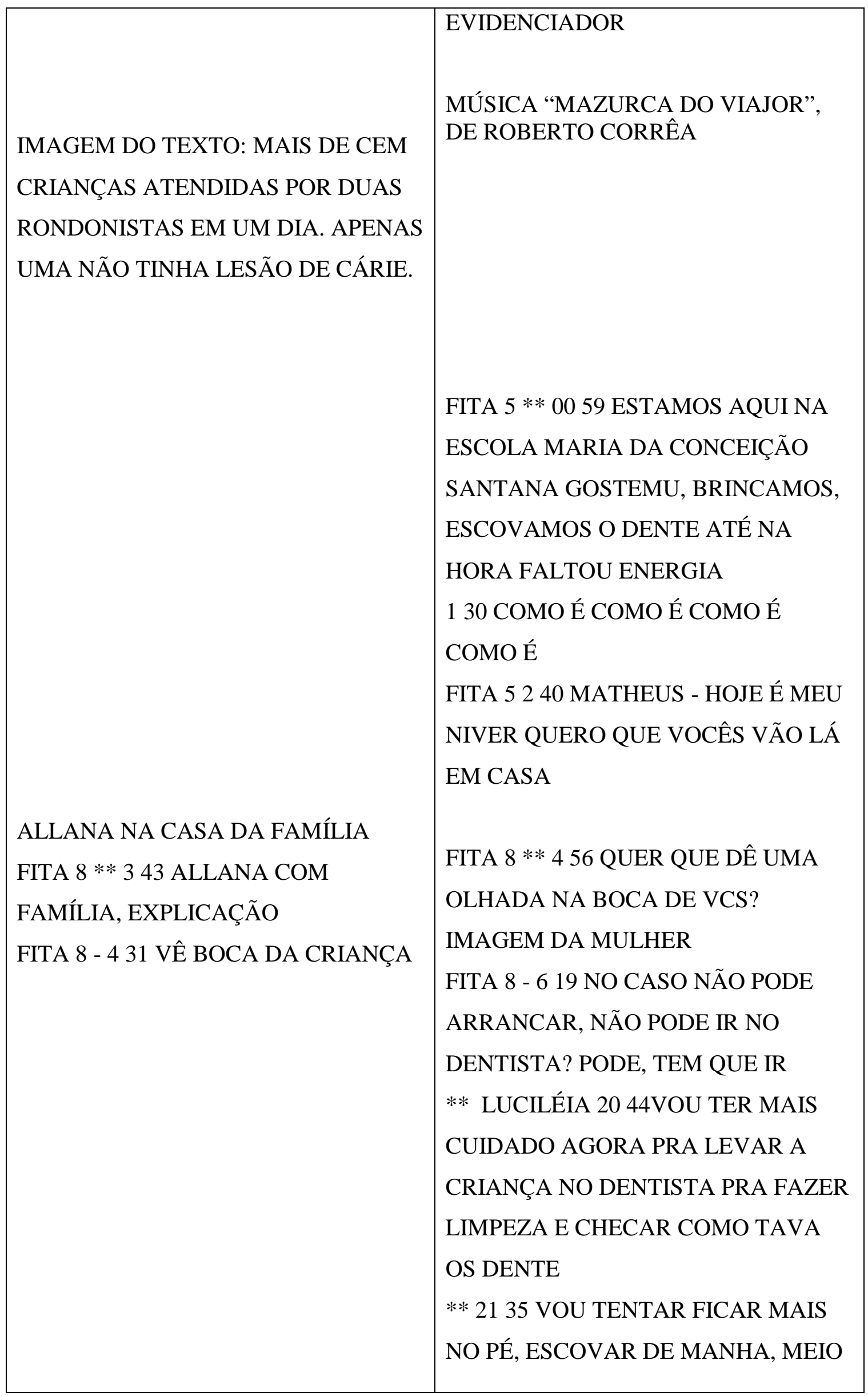




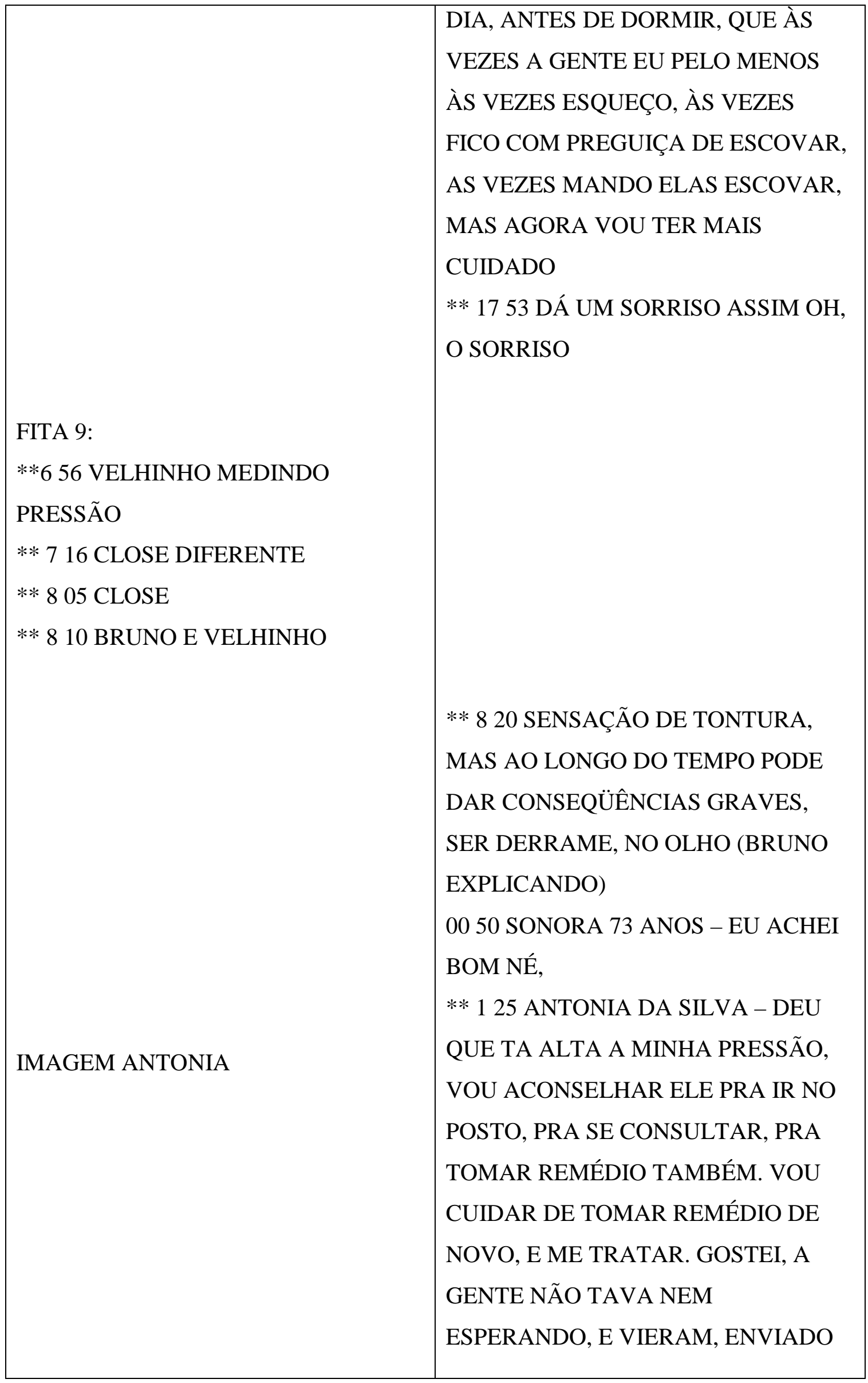




\begin{tabular}{|c|c|}
\hline & $\begin{array}{l}\text { DE DEUS, QUE DEUS QUE ENVIA AS } \\
\text { PESSOAS MESMO...NÃO TEM VINDO } \\
\text { GENTE AQUI SOBRE ESSES } \\
\text { TRABALHOS. }\end{array}$ \\
\hline IMAGEM FRANCISCA & $\begin{array}{l}\text { ** } 952 \text { FRANCISCA DA SILVA - PRAS } \\
\text { PESSOAS NOVAS É DIFÍCIL, PROS } \\
\text { IDOSO É MAIS. EU ESPERO QUE O } \\
\text { GOVERNO COM A AJUDA DE } \\
\text { VOCÊS, QUE ESTÃO SE } \\
\text { INTERESSANDO BASTANTE QUE } \\
\text { DEU ESSA VIAGEM TÃO GRANDE } \\
\text { AQUI NO INTERIOR PRA FAZER } \\
\text { ESSE TRABALHO, É MUITA } \\
\text { VONTADE MESMO. }\end{array}$ \\
\hline IMAGEM PREFEITO & $\begin{array}{l}\text { FITA } 07 * * * * 00 \text { SONORA DO } \\
\text { PREFEITO AMÓS BEZERRA DA } \\
\text { SILVA } \\
1306 \text { EU QUANDO ADOLESCENTE } \\
\text { TIVE O PRAZER DE RECEBER NA } \\
\text { NOSSA COMUNIDADE AQUI DE } \\
\text { AUGUSTO CORRÊA EU TINHA } 14 \\
\text { ANOS APROXIMADAMENTE } \\
\text { QUANDO EU VI A PRIMEIRA EQUIPE } \\
\text { DO PROJETO RONDON EM NOSSO } \\
\text { MUNICÍPIO, A REALIDADE É } \\
\text { DIFERENTE DAQUELA ÉPOCA } \\
\text { HAVIA UMA CARÊNCIA MUITO } \\
\text { GRANDE, MUITO MAIOR DO QUE }\end{array}$ \\
\hline
\end{tabular}




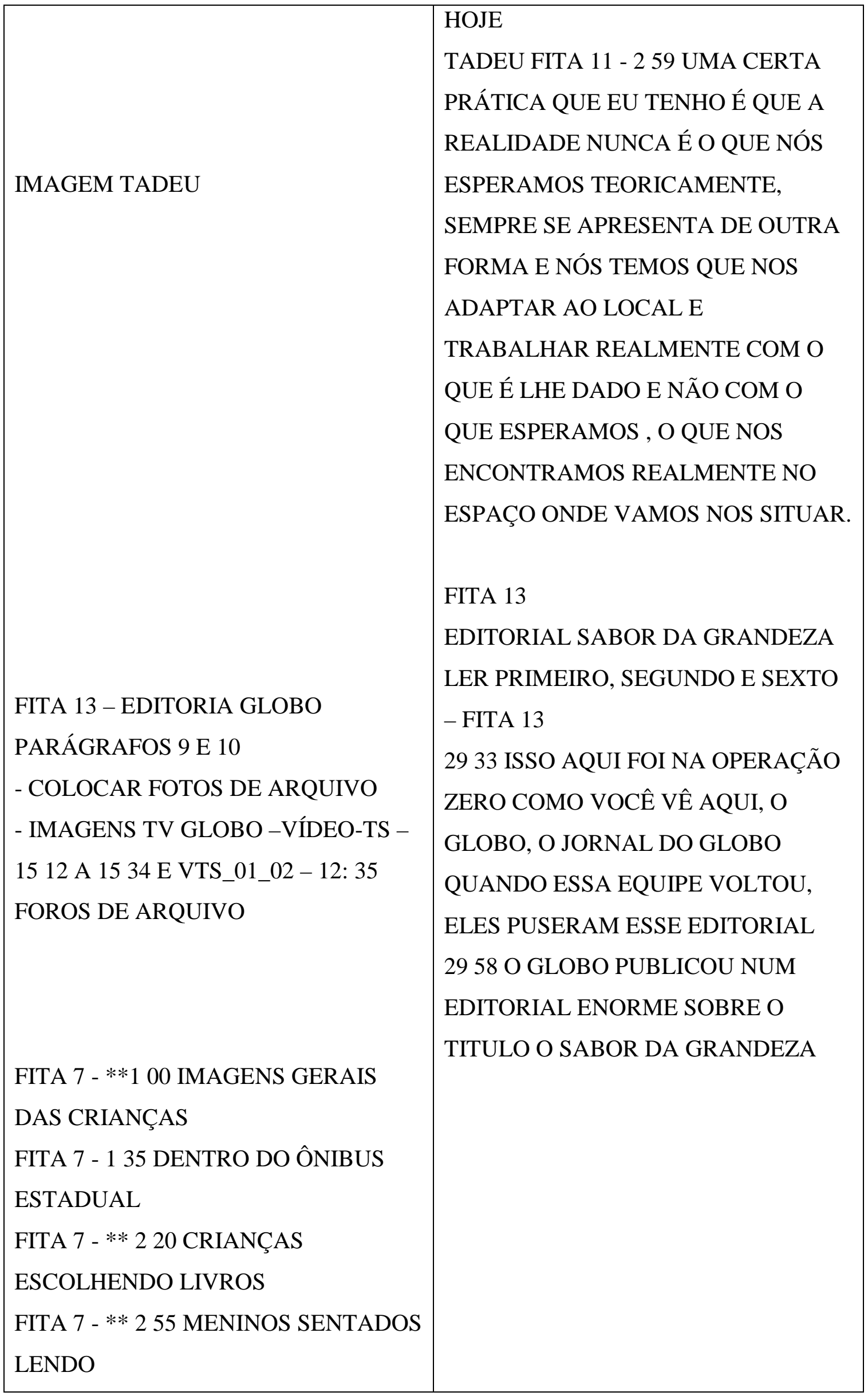




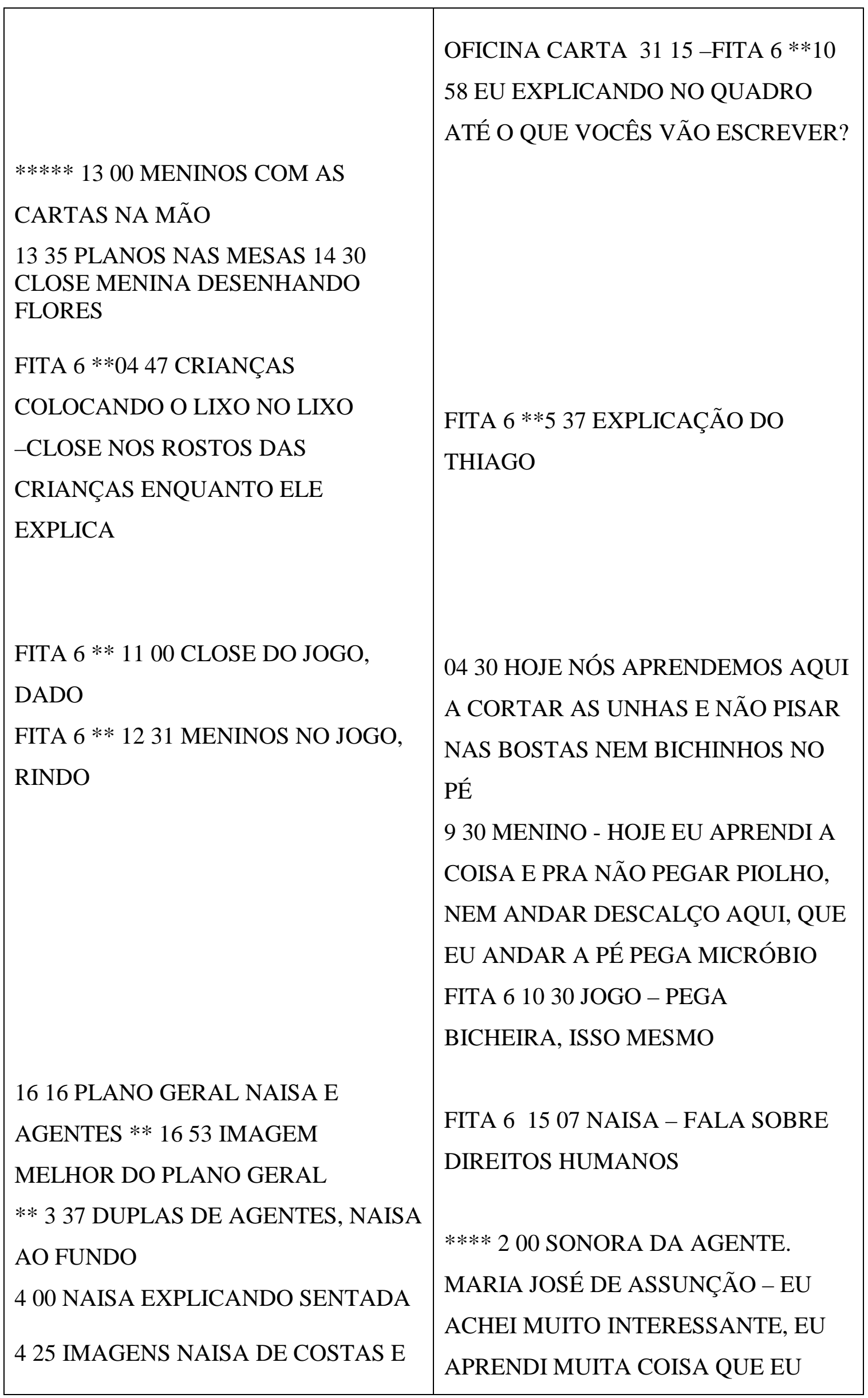




\begin{tabular}{|c|c|}
\hline $\begin{array}{l}\text { AGENTES DE FRENTE } \\
* * * * 0000 \text { IMAGENS DA AGENTE } \\
\text { COMUNITÁRIA ENTREVISTADA, } \\
\text { ELA ANOTOU TUDO DA AULA } \\
0102 \text { CLOSE NAS ANOTAÇÕES }\end{array}$ & $\begin{array}{l}\text { AINDA NÃO TINHA REALMENTE } \\
\text { MUITO CONHECIMENTO, PRA MIM } \\
\text { FOI UM PRAZER IMENSO TER } \\
\text { PARTICIPADO DESSA PALESTRA } \\
\text { COM VOCÊS AQUI E EU GOSTARIA } \\
\text { QUE VOLTASSEM VARIAS VEZES } \\
\text { PRA GENTE TER CONHECIMENTO } \\
\text { PARA PODERMOS PASSAR PARA AS } \\
\text { PESSOAS DA NOSSA COMUNIDADE } \\
\text { 02 51 EU APRENDI SOBRE OS } \\
\text { DIREITOS DO CIDADÃO NÉ, } \\
\text { DIREITOS E DEVERES, SOBRE A } \\
\text { VIDA DOS ADOLESCENTES, AS } \\
\text { CRIANÇAS } \\
\text { - PODE PASSAR ISSO PRA } \\
\text { COMUNIDADE? } \\
\text { - POSSO. } \\
\text { - COMO? } \\
\text { - EXPLICANDO DA MANEIRA QUE } \\
\text { EU ENTENDI AQUI, PODER } \\
\text { REPASSAR O QUE EU ENTENDI } \\
\text { AQUI MAIS OU MENOS NÉ... EU } \\
\text { ANOTEI MAIS OU MENOS } \\
\text { ALGUMAS COISAS }\end{array}$ \\
\hline IMAGEM DA SOCORRO & $\begin{array}{l}\text { FITA } 11 \text { - *** } 111 \text { BENEDITA } \\
\text { SOCORRO BARRETO, DIRETORA DE } \\
\text { ENSINO DA SECRETARIA DE } \\
\text { EDUCAÇÃO ESSA TROCA DE } \\
\text { EXPERIÊNCIAS TENHO CERTEZA } \\
\text { QUE A COMUNIDADE GANHOU } \\
\text { PORQUE O TRABALHO FOI } \\
\text { DESENVOLVIDO AQUI COM AS }\end{array}$ \\
\hline
\end{tabular}




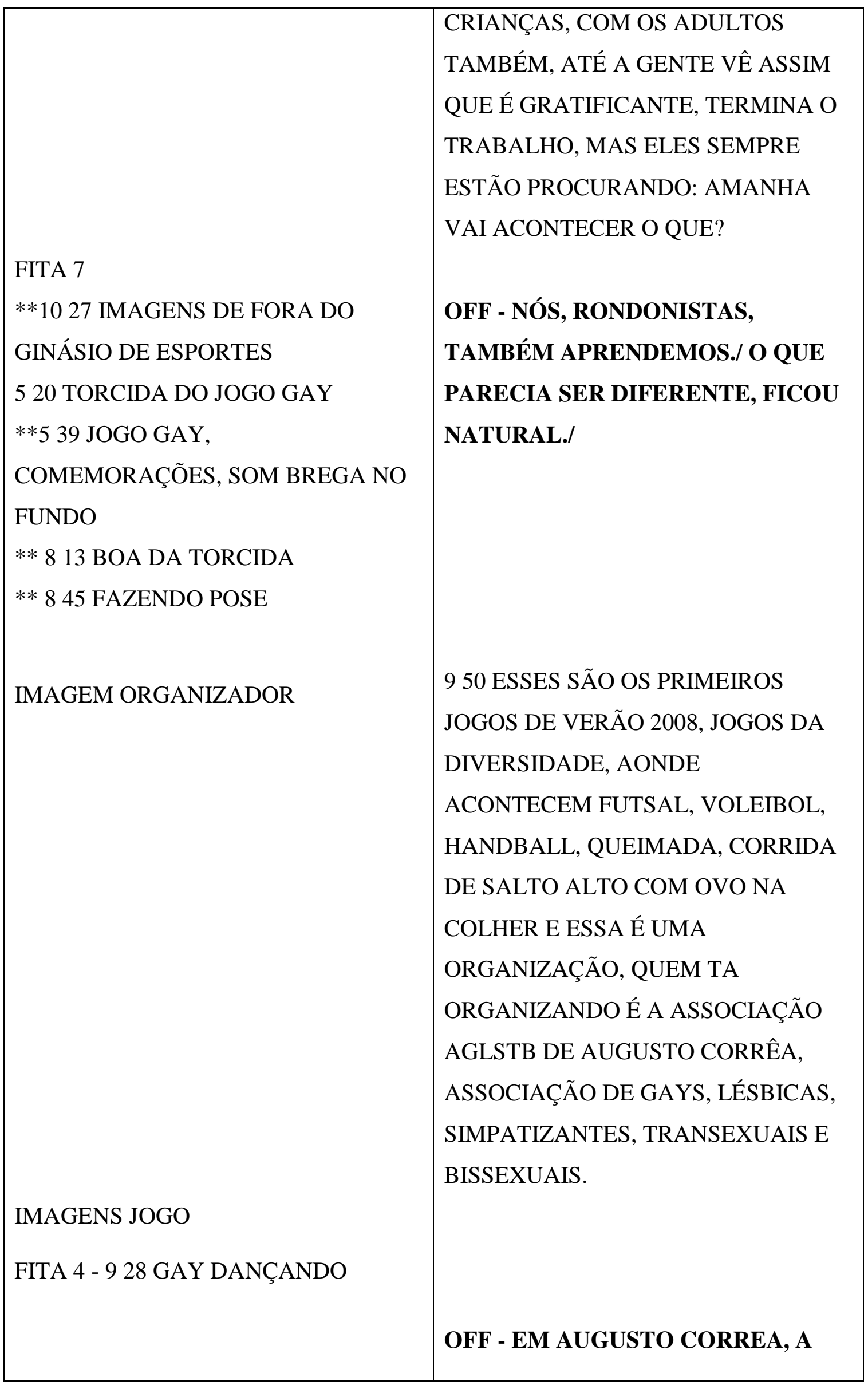




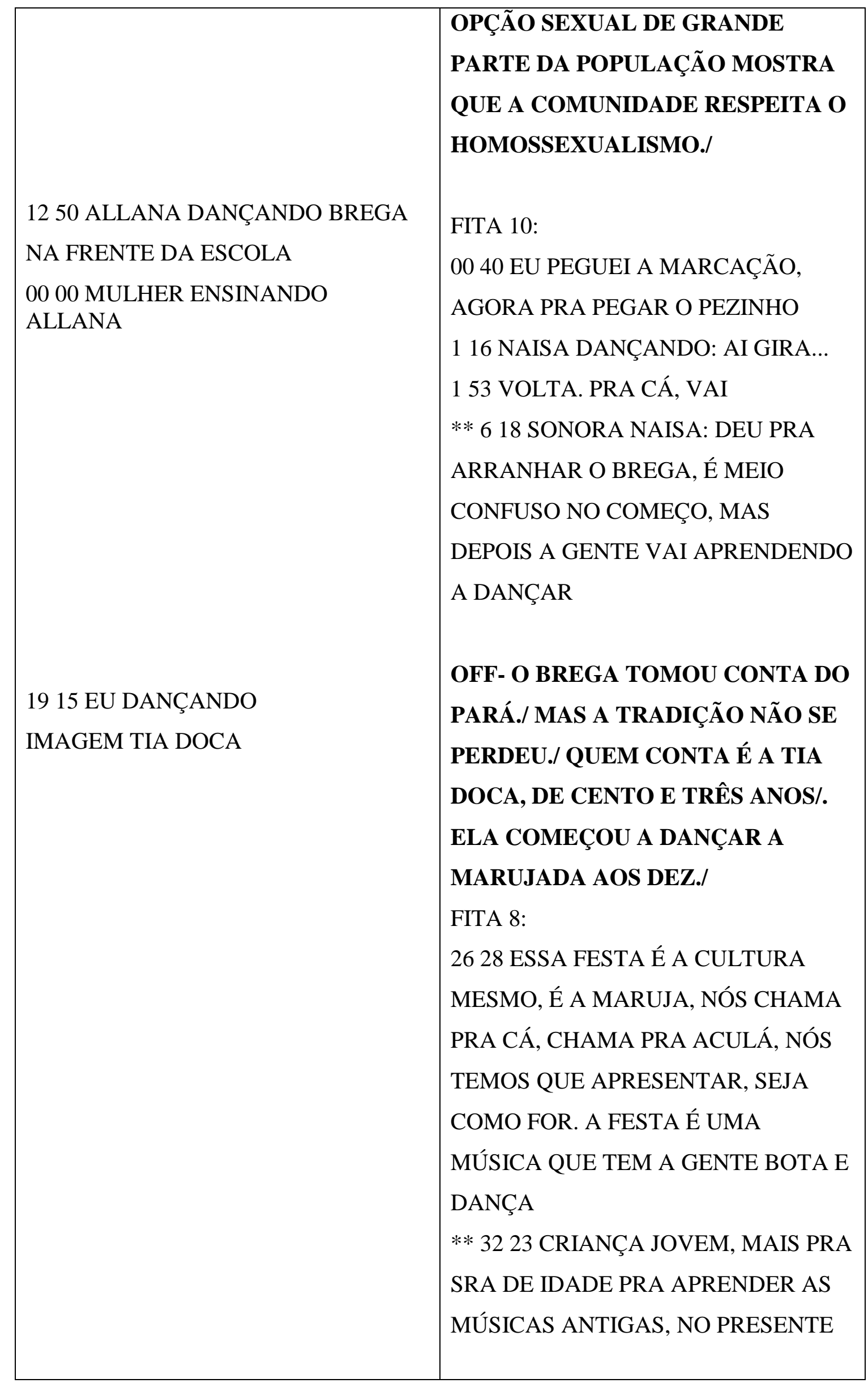




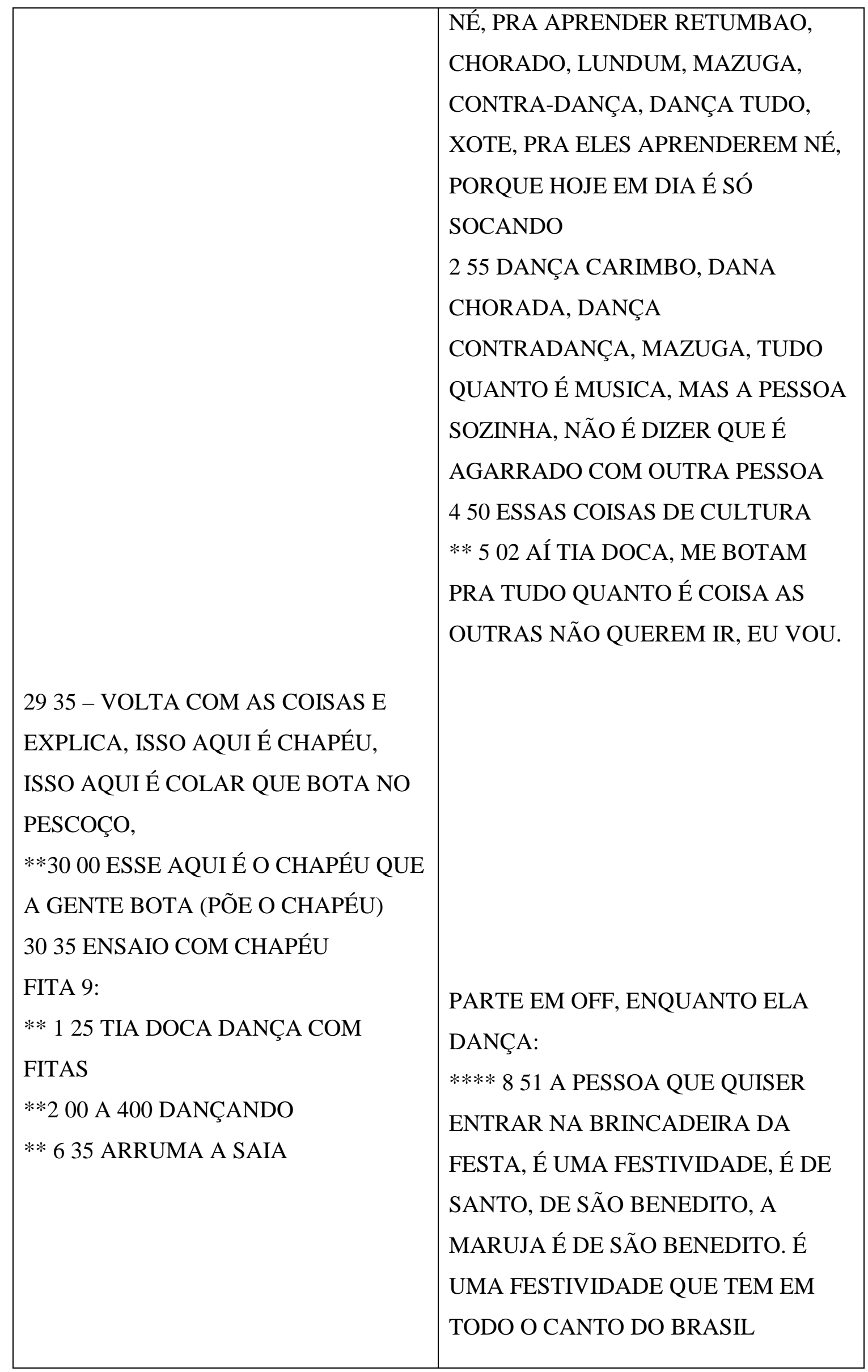




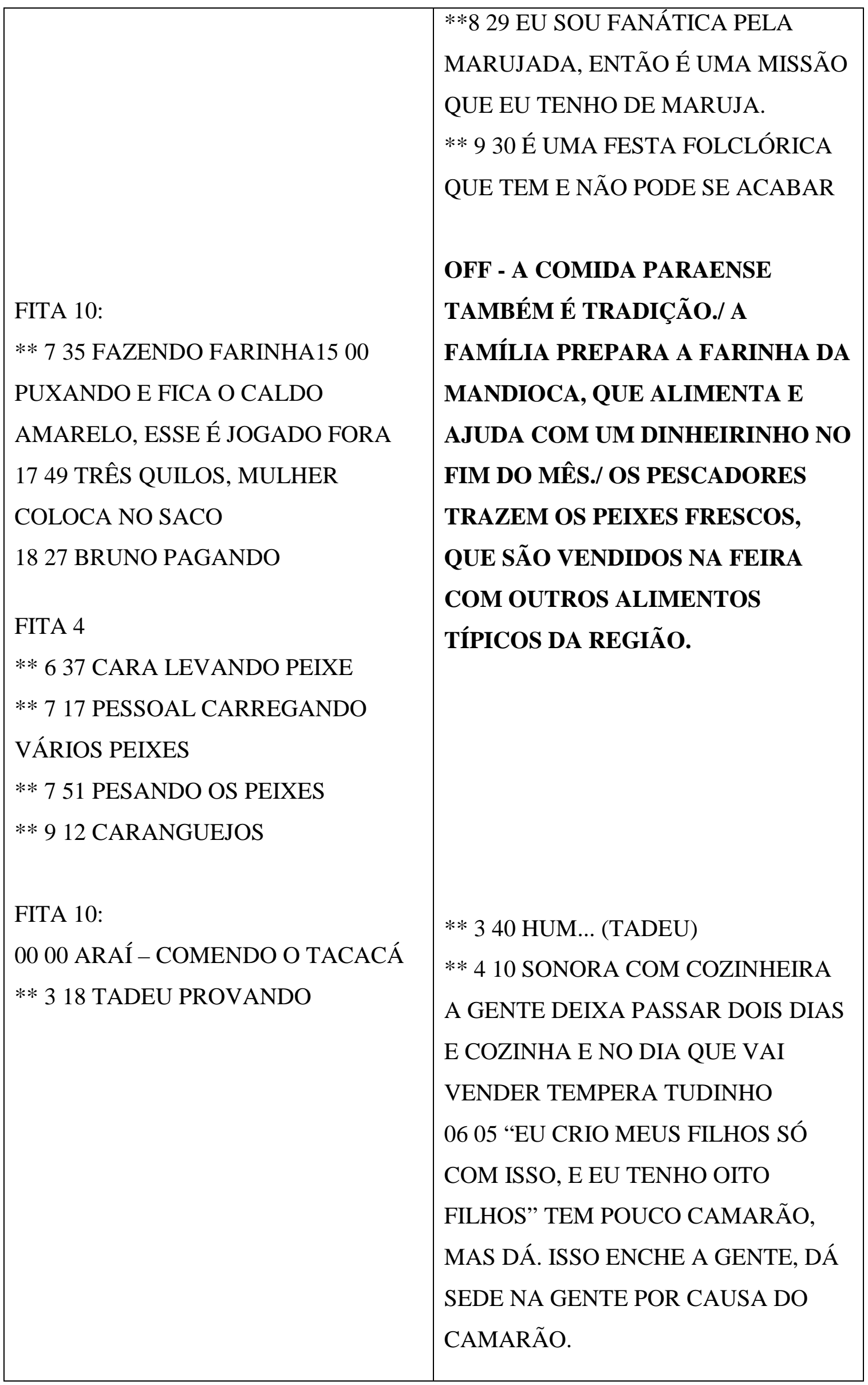




\begin{tabular}{|c|c|}
\hline IMAGEM NAISA & $\begin{array}{l}\text { ** } 1034 \text { NAISA: MINGAU DE MILHO } \\
\text { BRANCO COM FARINHA DE } \\
\text { TAPIOCA. TACACÁ É MAIS FORTE, } \\
\text { MAS O MINGAU É GOSTOSO, É MAIS } \\
\text { O PALADAR DA NOSSA REGIÃO }\end{array}$ \\
\hline ** 857 CLOSE NO TADEU COMENDO & $\begin{array}{l}\text { OFF - AQUELES DIAS DE PROJETO } \\
\text { RONDON MUDARAM NOSSO } \\
\text { PALADAR, NOSSO SENTIMENTO E } \\
\text { NOSSA VISÃO DE BRASIL. }\end{array}$ \\
\hline $\begin{array}{l}\text { FITA 9: } \\
2500 \text { ATÉ } 2630 \text { TENTATIVAS COM A } \\
\text { BANDEIRA DO BRASIL } \\
2150 \text { CLOSE CRIANÇADA } \\
2158 \text { TUM TUM TA (MARCO } \\
\text { ENSINANDO) } \\
2239 \text { COMEÇAM A ENTRAR NO } \\
\text { RITMO }\end{array}$ & \\
\hline $\begin{array}{l}* * 2414 \text { BATUCADA, CLOSE NOS } \\
\text { PAUSINHOS E DEPOIS GERAL DO } \\
\text { MARCO EXPLICANDO }\end{array}$ & $\begin{array}{l}\text { HINO NACIONAL - MIXAR COM } \\
\text { BATUCADA DOS MENINOS }\end{array}$ \\
\hline $\begin{array}{l}\text { FITA 03: } \\
0000 \text { HASTE DA BANDEIRA (MIXAR } \\
\text { COM HINO NACIONAL) } \\
* * 0010 \text { RONDONISTAS CANTANDO, } \\
\text { TADEU } \\
* * 207 \text { SARGENTO SOARES } \\
\text { CANTANTO } \\
* * 235 \text { IMAGEM ONÇA SE MEXENDO } \\
* * 306 \text { IMAGEM DOS SOLDADOS }\end{array}$ & \\
\hline
\end{tabular}




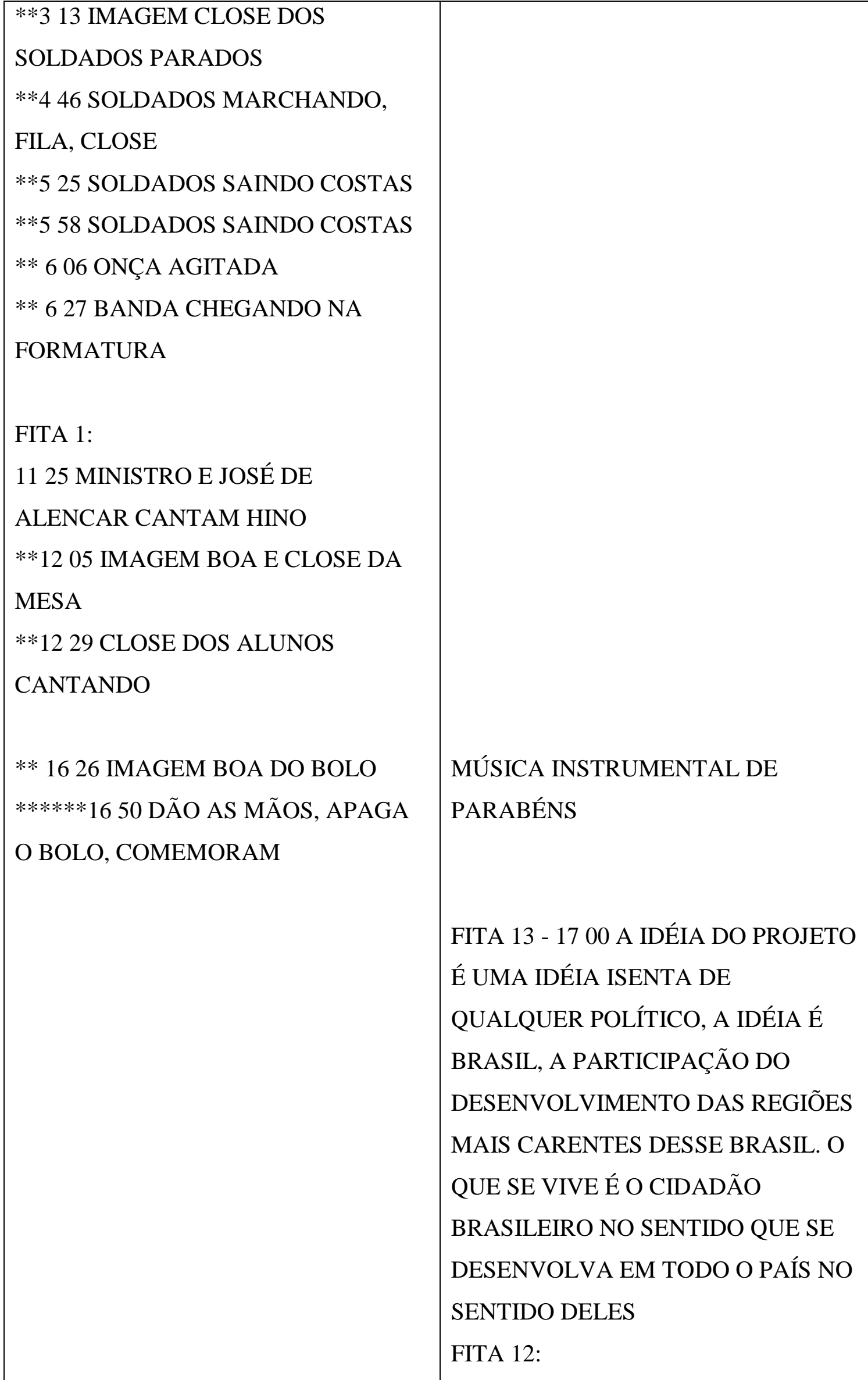




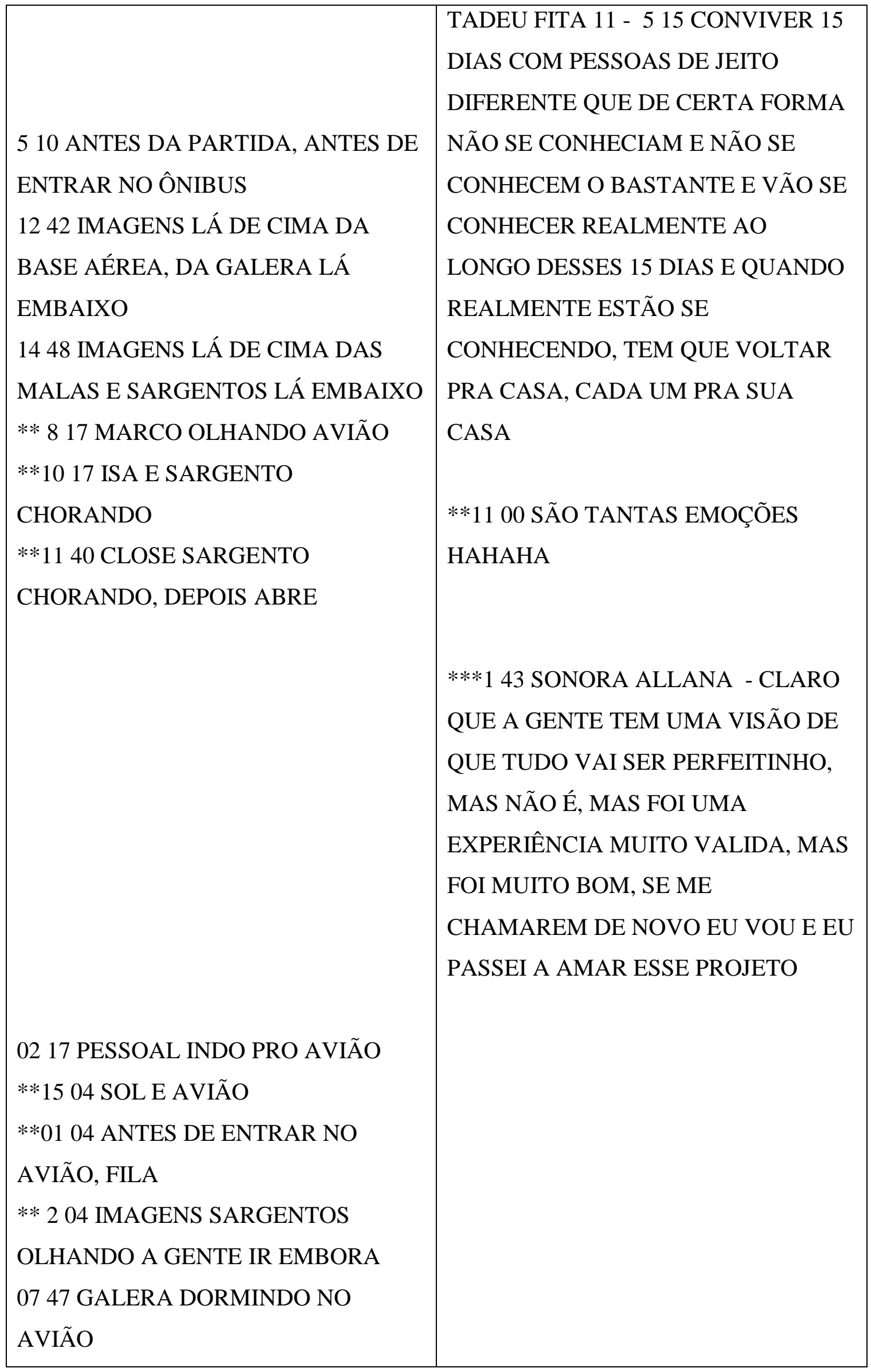




\begin{tabular}{|c|c|}
\hline \multicolumn{2}{|l|}{$* * 0300$ CABINE DO COMANDANTE } \\
\hline DO AVIÃO & \\
\hline 0413 CARA FAZENDO CONTAS & \\
\hline ** 0440 CLOSE LEGAL DO & \\
\hline COMANDANTE & \\
\hline **04 52 CARA FAZENDO CONTAS & \\
\hline 0510 FORMOSA, COM DESTINO A & ****06 20 FALA COM OPERAÇÃO \\
\hline BSB & RONDON \\
\hline 0529 CLOSE LEGAL - FALA & **** 0655 FALA DE NOVO RONDON \\
\hline RONDON & \\
\hline 0543 CLOSE LEGAL DO & \\
\hline COMANDANTE & \\
\hline 0603 OPERAÇÕES BSB, CLOSE & \\
\hline MAPA & **08 33 UHULLL CHEGAMOOOSS \\
\hline 0804 GALERA CHEGANDO, & MARCO VIVA \\
\hline PULANDO & \\
\hline FITA 7 - ** 110 TREMIDAS DO & FITA 13 - 2107 OFF DO PASQUALI - \\
\hline BURADO (ADVERSIDADES, & ESSA VIAGEM DEU-NOS UMA \\
\hline DIFICULDADES) & CERTEZA: NÃO BASTA OLHAR O \\
\hline FITA 9 - 1552 - IMAGEM LINDA DA & MAPA DO BRASIL ABERTO SOBRE A \\
\hline FLOR ROSA & MESA DE TRABALHO OU PREGADO \\
\hline FITA 4- ** 1238 ISA LEVANDO A & A PAREDE DE NOSSA CASA, É \\
\hline SRA & PRECISO ANDAR SOBRE ELE, \\
\hline FITA 4- ** 1305 PESSOAS VENDO & SENTIR DE PERTO, AS ANGUSTIAS \\
\hline OS CARTAZES & DO POVO, SUAS ESPERANÇAS, SEUS \\
\hline FITA 4**19 14 MENINA ENCARANDO & DRAMAS OU SUAS TRAGÉDIAS, \\
\hline A CÂMERA & SUA HISTORIA, SUA FÉ NO DESTINO \\
\hline FITA 4- 1339 CRIANÇAS & DA NACIONALIDADE, SÓ ENTÃO SE \\
\hline DESENHANDO NO CHÃO COM GIZ & COMPREENDA QUE A \\
\hline FITA 5 - 225 MENINOS AO LADO DE & RESPONSABILIDADE DESSA \\
\hline EROSÃO & GERAÇÃO É SIMPLESMENTE \\
\hline FITA 5 - 316 CASA AZUL QUE & FORMIDÁVEL. TUDO INDICA \\
\hline
\end{tabular}




\begin{tabular}{|l|l|}
\hline VENDE BANANA & POREM QUE AGORA COMEÇOU \\
FITA 54 25 CLOSE MENINHA BEBE & PARA ALEGRIA NOSSA A BATALHA \\
FITA $4 * * 1004$ THIAGO E CRIANÇAS & LONGAMENTE ESPERADA DA \\
FITA 07 ** 13 00 PESSOAL & INTEGRAÇÃO DOS NOSSOS IRMÃOS \\
CAPINANDO & ABANDONADOS NA COMUNHÃO \\
FITA 05** 05 BARCO E A & NACIONAL. \\
LÂMPADA NA FRENTE & \\
& MÚSICA “MAZURCA DO VIAJOR”, \\
& DE ROBERTO CORREA \\
\end{tabular}

